\title{
Humusica 2, article 15: Agro humus systems and forms*
}

\author{
Augusto Zanella ${ }^{a}{ }^{\dagger}$, Jean-François Ponge ${ }^{b}$, Stéphanie Topoliantz ${ }^{c}$, Nicolas Bernier ${ }^{b}$, Jérôme Juilleret ${ }^{d}$ \\ ${ }^{a}$ University of Padua, Italy \\ ${ }^{\mathrm{b}}$ Muséum National d'Histoire Naturelle, Paris, France \\ ${ }^{\mathrm{c}}$ Établissement Régional d'Enseignement Adapté, Ollainville, France \\ ${ }^{\mathrm{d}}$ Luxembourg Institute of Science and Technology, Belvaux, Luxembourg
}

Keywords: Humusica; Humus; Agriculture; Agro humus system; Agricultural soil structure; Soil structure; Agricultural soil classification; Soil biology; Soil biological structure; Anthropic mull; Soil and agriculture

\section{ABSTRACT}

Agro humus systems correspond to agricultural humipedons. Specific terms and diagnostic horizons are defined and topsoil profiles are described. With this new vocabulary, which focuses on the biological structure of the A horizon, we can compare these humipedons with their original natural expression. Under human pressure for agricultural purposes, natural humipedons evolve toward anthropic Mull (See Humusica 1, articles 5 and 6 for natural humus horizons) or Amphi (Mull with layers of still not incorporated $\mathrm{OH}$ organic horizons) humus systems. In each humus system, we define a few humus forms in order to estimate the biological health of the soil, with a rapid observation realisable in the field by the naked eye. Histic anthropic Anmoor is also possible, as well as Hydro or Epihistic intergrades to Terrestrial systems. WRB qualifiers and Soil Taxonomy subgroup adjectives are reported the end of the article and can be used for a more detailed classification.

Abbreviations: ST, USDA Soil Taxonomy; WRB, World Reference Base for Soil Resources

\footnotetext{
${ }^{*}$ Background music while reading? Vita contadina a Casnigo - primi anni del 1900: https://www.youtube.com/watch?v=1iDdjoBdptM

${ }^{\dagger}$ Corresponding author.

E-mail addresses: augusto.zanella@unipd.it (A.Zanella), ponge@mnhn.fr (J.-F. Ponge), stephanie.topoliantz@free.fr (S. Topoliantz), bernier@mnhn.fr (N. Bernier), jerome.juilleret@list.lu (J. Juilleret).
} 


\section{Introduction}

Agro humus systems arise from natural humipedons which have, been influenced (e.g., strongly or slightly modified, simplified, fertilized) by man with the purpose of temporary or permanent food production or growing vegetation for various economic purposes. Agro humus systems correspond to agricultural or urban soils, tilled, shallow or deep ploughed, amended with organic and/or mineral fertilizers. Monocultures, rotation crops, arboriculture, grazing, fertilization, pesticides and herbicides are in current use in most of these soils, depending on the type of agriculture, and the main properties of the original humus systems are more generally no longer recognizable because they have been strongly modified by man. However, in Agro humus systems we can find structures and soil trophic networks displaying the natural expression of life. The purpose of our classification is first to "circumscribe and describe" the present-day humipedons. For that, we defined some specific terms used in the description. Second, we indicated the nearest natural reference for eventual actions of physical-chemical restructuration and biological reactivation of the modified humipedon to address the issues of soil protection and sustainable agriculture.

The classification of Agro humus systems is made by analogy with the natural humus systems and forms presented in other chapters of Humusica 1 and 2. The name attributed to each anthropogenic humipedon corresponds to the "nearest natural humus system, regarding all its morpho-functional aspects". The important thing is not the land use or the human goal, but that pragmatically we may notice deviations from former natural systems.

Our main objective is to have at our disposal a practical tool for comparing different agroecosystems on the base of features directly observable on the field by our naked eyes, without resorting to tedious laboratory analyses, which need time and money and give us only an indirect and partial view of the biological quality of agricultural soils. We insist on the well-known fact that soil fertility is not synonymous of soil health (Kibblewhite et al., 2008). The present chapter of the Humusica field manual should not be considered as a review. We are unable to embrace the immense variety of farming systems prevailing worldwide (http://www.fao.org/farmingsystems/; http://www.globalagriculture.org/report-topics/industrial-agriculture-and-smallscale-farming.html). The examples which are treated in this article concern the own experience of the authors, limited to European agricultural landscapes, and more especially those of western Europe, awaiting fructuous exchanges with readers from other regions of the world. Our classification system is still in infancy, being novel for science and thus prone to many improvements.

\section{Specific terms}

For describing these humus systems, Topoliantz et al. (2000) used soil structure as a main discriminant parameter. In this chapter, we adapted the terms proposed by Topoliantz et al. (2000) for a practical definition of Agro diagnostic horizons. In fact, by the naked eye or with the help of a magnifying lens $(10 X, 15 X)$, a field observation of the structure of the A horizon allows individuating a few useful specific features and diagnostic horizons. Terms describing the structure of humus 
profiles, such as biomacro-, biomeso- and biomicrostructure, and many other terms used in this manual (e.g. ped, humipedon, codes for diagnostic horizons) have been defined and illustrated in Humusica, article 4, to which the reader of this chapter is referred.

\subsection{Structureless massive material}

Large (> $10 \mathrm{~mm}$, commonly 10-20 mm) irregular peds, the edges of which are irregularly angular shaped, as when breaking off a homogeneous crusty mass. Porosity limited to some poorly developed root channels. The structure cannot be broken up by hand in aggregates. No faunal excrements are visible (Fig. 1). Structure (IUSS Working Group WRB, 2015): massive, platy or cloddy. If the soil is dry, when applying moderate to strong pressure with fingers, the soil sample progressively breaks up into finer artificial units; these fine units have a varying mineral, organicmineral or organic composition; if the soil is moist, the sample can be transformed into a tender, plastic, non-elastic matter. This structureless massive material may compose massive $A$ horizons of natural soils (msA, described in Humusica 1, article 4).

\subsection{Structureless single grain material}

Unbound fine mineral and organic particles of loose consistence. Presence of clean (= uncoated) sand grains, calcareous and/or siliceous. Dark-coloured biogenic (holorganic or hemorganic) peds $<10 \%$ of volume estimated by naked eye (Fig. 2 ).

\subsection{Granular and finely granular materials: biomacrostructured material}

Soil material composed of rounded eroded peds (Fig. 3) corresponding to recognizable anecic and endogeic earthworm faeces, even if aged or more or less degraded (Figs. 4a and b). When observing a soil sample larger aggregates (granular material) can be detected (Fig. 3). They are made of finer structures (finely granular material, Figs. $4 a$ and b). When pressed between fingers the larger aggregates are reduced in smaller aggregates. For doing this operation, a relatively strong force has to be applied while the soil is dry; when the soil gets wet, aggregates become malleable, breaking easier in a first time, then forming a clayish plastic mass. When set dry on a sieve (mesh size $4 \mathrm{~mm}$ ) and gently shaken, dry granular and finely granular material divide in two parts: one refused on the sieve (grains $>4 \mathrm{~mm}$ ) and one passing through the mesh (grains $\leq 4 \mathrm{~mm}$ ). The first aggregate unit is identified as biomacrostructured material.

\subsection{Very finely granular material: biomesostructured and biomicrostructured materials}


Soil material composed of small well-individualized aggregates, resulting from the activity of small endogeic worms or large enchytraeids. It can be observed in the top first centimetres of agricultural soils, in admixture with strongly decayed plant remains (Figs. 5a and b). Often the larger structures under transformation correspond to old earthworm droppings, more or less compacted and eroded. In Figure 5a, we report a large $(3-5 \mathrm{~mm})$ structure made of smaller grains $(<1 \mathrm{~mm})$. The first structure may break up in smaller grains, which are made of even finer grains (Fig. 5b). When set dry on a sieve (mesh size $1 \mathrm{~mm}$ ) and submitted to gentle shaking, a very fine granular material shares in two sub-units, one with grains larger than $1 \mathrm{~mm}$ remaining on the sieve and the other with a dimension $\leq 1 \mathrm{~mm}$ passing through the mesh. These two parts of the sample are called biomesostructured and biomicrostructured materials, respectively.

\section{Agro diagnostic horizons}

In addition to the diagnostic horizons that characterize natural Terrestrial, Histic and Para humipedons, other anthropogenic diagnostic horizons are necessary to describe Agro systems. Five anthropogenic organic-mineral Agro A horizons are easily recognizable incrop fields when looking carefully at their structure:

- poorly zoogenic A horizons: 1) massive or 2) single grain;

- richly zoogenic A horizons: 3 ) biomicrostructured or 4) biomesostructured or 5) biomacrostructured.

This simplified classification has been conceived sharing horizons poor or rich in burrowing (structure-building) pedofauna. Massive (Fig. 1) or single grain (Fig. 2) materials are related to poorly zoogenic soil horizons; granular, fine granular (Figs. 3 and 4) and very fine granular materials (Fig. 5) are related to zoogenic horizons.

Intensive agriculture (e.g., deep tillage, heavy grazing, extensive use of mineral fertilizers and pesticides) increases the content in structureless massive material and decreases the content in biomacro-, biomeso- and biomicrostructured materials (Barratt, 1967; Topoliantz et al., 2000; Brittain et al., 2010). Original naturally fauna-rich $m a A$ and meA horizons may progressively become impoverished in pedofauna, becoming in a first step zoogenic amaA and ameA, then poorly zoogenic amsA, and finally non zoogenic msA horizons; in better filtering sandy soil texture structureless single grain material may become dominant, masking the effect of decreased biodiversity. As a general rule, the disappearance of the activity of large invertebrates makes more visible the activity of smaller animals, because bigger animals ingest droppings of smaller animals and transform them in bigger droppings, thereby increasing the size of aggregates. Upon elimination of anecic earthworms (creating amaA) by deep ploughing (Chan, 2001) and pesticide use (Pélosi et al., 2013, 2014), the structure realized by smaller annelids (small endogeic worms, large enchytraeids) is revealed (ameA). Then, when these small annelids are in turn eliminated by intensive agricultural practices, the structure created by small enchytraeids is revealed (amiA) until traces of animal activity completely disappear (amsA). 
The use of a digital scale (Fig. 6) may help estimating on the field the volume of aggregates in case of neither massive structure nor heavy (clayish) soil texture. Some field experience is nevertheless necessary for dispersing with fingers a sample of soil and put it in a first sieve (mesh = 4 $\mathrm{mm}$ ), lying over a second sieve (mesh $=1 \mathrm{~mm}$ ), the whole positioned on a final collector. Shaking the pile of sieves plus the collector shares the sample in three parts, corresponding to macrostructured (top), mesostructured (middle) and microstructured (bottom) material. It is strongly recommended to observe carefully with the naked eye the humus profile in place and to estimate the volume occupied by macro-, meso- and microstructured materials.

This procedure cannot be used in sandy soil, because all sand particles are retained by the second sieve, making confusion between mesostructured and microstructured material. For the estimation of clayish soil samples, sieves are also of no use because soil blocks will remain untouched on the upper sieve. When wanting to see if a poorly zoogenic $A$ horizon is evolving toward a more faunal active horizon, it is mandatory to share by naked eye structureless massive material from more biologically processed materials. For all these operations, Figures $1-5$, and some personal field experience are necessary. Here down more precise definitions of these Agro diagnostic horizons and some photographs of them are presented.

\subsection{Anthropogenic massive A horizon (amsA)}

Poorly zoogenic A horizon characterized by a dominance in volume of "structureless massive material" ( $>2 / 3$ in volume estimated by naked eye when observing the $A$ horizon in place in the profile) (Fig. 7). Morphologically similar to natural msA (observed in acid or heavy topsoils which are generally poor in pedofauna, see chapter 2.2), amsA corresponds to topsoils with a low activity of pedofauna due to the intensity of agricultural pressure (e.g., pesticide use, mechanical pressure of heavy machinery) (Figs. 1 and 8). This horizon is more often found in conventional farming systems with deep-ploughing and rotary tillage (Figs. 14a-c) or in farming systems with reduced tillage but high chemical input. In these cases the original biogenic structure of the A horizon is replaced by large blocks (5-10 cm or more, i.e. lumpy structure) of massive organic-mineral material which can display hydromorphic (anoxic) properties even when not in wet condition. In contrast with natural A horizons, these large blocks are poorly interconnected (only by plant roots) and spaces between them are large (several centimetres). Earthworm channels may be observed but many among them are disconnected and thus do not form a functional network.

To be identified as Anthropogenic massive A horizon (amsA), a layer must display the following properties (Figs. 8a-f):

- A horizon with volume of structureless massive material $>2 / 3$ of the entire volume of the horizon, estimated by naked eye and observing the horizon in place in the soil profile;

- large physical-chemical (not biological) peds $(>5 \mathrm{~cm}$ ): heterogeneous but one-piece, no planes or zones of weakness (cracks) are detectable in the mass;

- structure (IUSS Working Group WRB, 2015): massive, platy or cloddy. If the soil is dry, when applying moderate to strong pressure with fingers, the soil sample is progressively broken up 
into finer artificial units; these fine units have a varying mineral, organic-mineral or organic composition; if the soil is moist the sample can be transformed into a tender, plastic, nonelastic matter;

- traces of current biological activity possible: organic or organic-mineral pellets generated by arthropods or enchytraeids, earthworm droppings in any case $<10 \%$ of the soil volume (below this threshold their presence cannot be adequately recorded).

\subsection{Anthropogenic biomicrostructured A horizon (amiA)}

Horizon with dominance in volume of structureless single grain or/and microstructured materials ( $>2 / 3$ in volume estimated by naked eye when observing the $A$ horizon in place in the profile) (Figs. 2 and 9). In amiA there is at least 10\% in volume of organic particles and dark-coloured biogenic peds (holorganic or hemiorganic aggregates = humic component). Similar to natural $\mathrm{miA}$ (observed in topsoils dominated by enchytraeid activity, see Humusica 1, article 4, chapter 2.2), but deeper because of the mechanical incorporation of straw and/or organic amendments, the amiA horizon is encountered in exploited sandy soils or in loamy soils with deep ploughing and high pesticide use (Topoliantz et al., 2000; Stoate et al., 2001). In this case, man intervention may compensate for the lack of burrowing earthworm activity by increasing artificially its organic matter content and the depth of the humipedon (Balesdent et al., 2000).

Natural or anthropogenic sgA (single grain A horizon): dark-coloured (holorganic or hemorganic) peds $<10 \%$ of volume estimated by naked eye (Fig. 2);

Anthropogenic amiA: dark-coloured (holorganic or hemorganic) peds $\geq 10 \%$ of volume estimated by naked eye.

To be identified as Anthropogenic microstructured A horizon (amiA), a layer must display the following properties (Figs. 10a-d):

- all sizes of peds make more than $10 \%$ of the soil volume, observable both in situ, in undisturbed soil, and after gently squeezing a sample of soil in hand palm;

- volume of peds $>4 \mathrm{~mm}$ less than $10 \%$;

- volume of microstructured material $(\oslash \leq 1 \mathrm{~mm}$ ) rising at least to $2 / 3$ of the volume of the horizon; gently squeezing the soil, almost all large peds are easily reduced into smaller units;

- structural grade (FAO, 2006): moderate, strong; shape: granular; size: very fine $(<1 \mathrm{~mm})$;

- presence of (generally uncoated) sand grains (mineral components $>10 \%$ );

- organic particles and dark-coloured biogenic peds (organic or organic-mineral peds =humic component) $\geq 10 \%$ of the horizon volume;

- living microarthropods, small enchytraeids or their droppings.

In order to illustrate the changes induced in the humipedon by intensive agriculture we took advantage of the fact that the abovementioned ploughed field with amiA (Figs. 10a-d) was set aside a natural forest. We went in the forest and opened a humus profile (Figs. 11a and $b$ ). The humus system corresponds to a Mull and the humus form to a Dysmull, i.e. the less active form of the Mull 
system that may gradually pass to the Moder system. An incipient $\mathrm{OH}$ horizon is visible on Figure $11 \mathrm{~b}$ and reveals the local presence of a different humus form belonging to the Moder system, called Eumoder. While absent from the crop field, forest litter feeds the soil pedofauna, and the latter in turn increases the content in organic carbon of the topsoil (De Nicola et al., 2014), which appears darker in the top first $20 \mathrm{~cm}$.

\subsection{Anthropogenic biomesostructured A horizon (ameA)}

A horizon with cumulated volume of granular and fine granular material (Figs. 3 and 4) and very fine granular material (Fig. 5) equalling or exceeding the volume of structureless materials and where single grain material is less than $2 / 3$ of horizon volume (Fig. 9). This horizon corresponds to a modified biomesostructured natural horizon (meA, reported in Humusica 1, article 4). It is generally associated with integrated or sustainable farming systems, combining reduced tillage and minimum chemical input (EI Titi and Ipach, 1989). This horizon is rare in conventional agriculture (Hamza and Anderson, 2005) or under reduced tillage with high chemical input (Topoliantz et al., 2000).

To be identified as Anthropogenic biomesostructured A horizon (ameA), a layer must display the following properties (Figs. 12a-d and Fig. 99):

- cumulated volume of granular, fine granular and very fine granular materials greater than the volume of structureless massive material, estimated by naked eye and when observing the horizon in place in the soil profile, and

- volume of mesostructured material $(1<\oslash \leq 4 \mathrm{~mm})$ greater than the volume of macrostructured material $(\oslash>4 \mathrm{~mm})$;

- macrostructured material $<1 / 3$ of horizon volume;

- microstructured material $(\emptyset \leq 1 \mathrm{~mm})<2 / 3$ of horizon volume;

- presence of living endogeic earthworms, macroarthropods or large enchytraeids; or presence of droppings of these animals;

- $\mathrm{pH}_{\text {water }}>5$.

\subsection{Anthropogenic biomacrostructured A horizon (amaA)}

A horizon with a volume of granular and fine granular material $(\oslash>4 \mathrm{~mm}$ ) (Figs. 3 and 4 ) greater than the volume of structureless massive material (Fig. 1); volume of biological macropeds $(\oslash>4 \mathrm{~mm}$ ) rising at least $1 / 3$ of the volume of the horizon sample (Figs. 7 and 9 ). It is rare (only in pockets) in soils with high chemical input and/or intensive tillage (Topoliantz et al., 2000). The amaA horizon corresponds to a man-modified biomacrostructured (maA) natural horizon. It is rare in intensively mechanically worked soils or under high input of pesticides and fertilizers (Hamza and Anderson, 2005; Topoliantz et al., 2000). It is favoured by no-tillage or reduced-tillage agriculture (Carter, 1991; Six et al., 2000; Ernst and Emmerling, 2009) and organic farming (Mäder et al., 2002). 
To be identified as Anthropogenic biomacrostructured $\mathrm{A}$ horizon (amaA), an A horizon must be present in a man-modified environment and must display the following properties (Figs. 13a-c and Fig. 9 ):

- volume of granular and fine granular material greater than the volume of structureless massive material, estimated by naked eye and by observing the horizon in place in the soil profile;

- volume of macrostructured material $(\oslash>4 \mathrm{~mm})$ at least $1 / 3$ of the horizon volume;

- presence of living earthworms, or earthworm burrows and/or casts;

- $\mathrm{pH}_{\text {water }}>5$.

\subsection{Dynamic relationships between Agro horizons}

These four Agro horizons are dynamically related (Figs. 14a and b). The Anthropogenic biomacrostructured $\mathrm{A}$ horizon ( $\mathrm{amaA}$ ) is the richest in burrowing animal activity (anecic earthworms, considered as soil ecosystem engineers, Jouquet et al., 2006), the others being considered as impoverished derivatives. The Anthropogenic biomesostructured A horizon (ameA) is still rich in endogeic earthworms but has lost part of the complete faunal trophic network (Fig. 14a, arrow 1). In the absence of anecic earthworms, known for their sensitivity to deep ploughing and high pesticide use (Geiger et al., 2010; Pélosi et al., 2013; Ponge et al., 2013), endogeic earthworms replace them as ecosystem engineers in the creation of a soil structure. However, endogeic earthworms are unable to bury superficial organic matter, and then Man must replace them by mechanical treatment in order to create a cultural humipedon. In the absence of tillage ameA would degenerate in amiA underlying an $\mathrm{O}$ horizon, because endogeic earthworms are unable to reach the organic matter which is deposited at the soil surface, contrary to anecics (Eisenhauer et al., 2008).

The Anthropogenic microstructured A horizon (amiA) corresponds to soils which are acidified (after leaching of a soil deprived of vegetation cover), deficient in nutrient and water resources (dry, sandy soils), and/or submitted to heavy pesticide use for sustaining more than a specialized pioneer enchytraeid fauna (Fig. 14a, arrow 3). The amiA horizon may correspond to sandy A horizons amended for specific cultures (e.g., asparagus, carrot). The Anthropogenic poorly zoogenic massive A horizon (amsA) takes place (Fig. 14a, arrow 2) in heavy anoxic soils (a character often revealed by small orange-grey patches) or in intensively exploited soils. In these soils, a few animals may subsist, escaping seasonal drought and pesticides by digging down into the soil before arrival of ploughing machines or by diapausing (Lavelle, 1988; Holmstrup, 2001). With an excessive anthropic pressure on these humipedons, amsA and asgA become completely devoid of fauna in heavy and filtering soils, respectively (Fig. 14a, arrow 4).

It is also interesting to compare anthropogenic structures and natural structures from which they derive (Fig. 14b). We can state that anthropogenic structures stay halfway between zoogenic and non-zoogenic natural structures. It is relatively easy to maintain a nearly natural equilibrium by feeding poorly zoogenic soils with compost or organic-rich manures, thus realizing the natural work 
of pre-transformation of litter out of the field and directly feeding soil organisms with well-humified and "ready-to-use" organic matter.

Finally we can enumerate the following natural and artificial A diagnostic horizons:

- Natural (or semi-natural: indirectly influenced by Man):

0 non zoogenic: massive ( $\mathrm{msA}$ ) and single grain (sgA) horizons;

0 zoogenic: micro (miA), meso (meA) and macrostructured (maA).

- Man strongly influenced, agricultural soils:

0 poorly zoogenic: massive (amsA) and single grain (asgA) anthropogenic horizons;

0 zoogenic: micro (amiA), meso (ameA), macrostructured (amaA) anthropogenic horizons.

The use of compost may add fauna and organic matter to poorly zoogenic soils. This process can improve and restore heavily or badly exploited soils (Tejada et al., 2009). Compost and other manures are presented in Humusica 2, article 16 dedicated to Techno humus forms, i.e. humus forms made by man using natural or artificial components.

\subsection{The perturbation of soil horizons by cultural practices}

It is well-known that tillage, whether superficial or deep, creates anomalies in the vertical distribution of organic matter and soil organisms when fresh residues are ploughed in (Six et al., 1999). In particular, we can observe temporary inversions in the distribution of soil fauna a short time after organic-rich horizons have been turned up (authors' personal observations). We may wonder whether this may have consequences for the observation of diagnostic horizons in agricultural humipedons. Our answer is no, because what we want to observe in an Agro system is the result of the combined influence of natural (e.g., microbial, faunal) and artificial (e.g., tillage, harrowing, chemical or organic input) processes, and should be taken as such. In this article, we show that a crust is often present at the soil surface under the influence of slaking (Figs. $1 \mathrm{~b}$ and $15 \mathrm{~d}$ ). Below this crust, the structure created by living organisms is observable to the naked eye and can be identified and classified. At deeper levels, compaction often occurs (Fig. 15c).

The use of disc harrow or superficial rotary tiller is common after ploughing, and divides the soil profile in two parts visible to the naked eye: a fragmented topsoil $(20 \mathrm{~cm})$, corresponding to granular material, lying on a much more compact bed made of massive material (Figs. 8a-f and Figs. 15a-c). A physical crust is visible at the top, due to a three-step process: rain drop impacts, slaking of the top first millimetres, and water evaporation (Awadhwal and Thierstein, 1985). A blade can be relatively easily pushed into the till down to $20 \mathrm{~cm}$, while it is very difficult to push it further into the soil with the hands; feet and body weight are necessary for ploughing further the blade into the massive material that forms the plough-pan.

It is interesting to compare such soil with a soil not ploughed for the last 7 years and treated with organic manure by the University of Padua (Fig. 16a-e). A crust is visible even on this biologically better soil (Figs. 16a-c). With hands is very easy to push a blade into such a soil and here, even at $40-$ 
$50 \mathrm{~cm}$ depth, the soil remains granular (Figs. $16 \mathrm{~d}$ and e). The observed material is never massive. The soil has been rotary tilled (see a strip of about $2 \mathrm{~m}$ on the right side of Figure 16a). A comparison with the naked eye of the soil structure of tilled against untilled strips showed that even superficial rotary tillage was unnecessary for having a well-structured soil. The rotary-tilled strip presented only a little finer soil structure, but probably not more functional than the slightly coarser one observed in the untilled soil (Figs. 16c and d).

\section{Urban humipedons are Agro humus systems}

Agricultural humipedons, even when strongly influenced by Man with the purpose of growing plants, are generally Agro humus systems. Looking carefully at them, we can recognize natural or anthropic humus horizons and often identify the humipedons as Agro humus forms. Sometimes it is even possible to classify them as more natural humipedons, selected among Terrestrial, Histic, Hydro or Epihistic intergrades and Para (see other chapters of Humusica 1 and 2 devoted to these systems).

In urban humipedons it is often possible to find "artefacts" (generally human-made wastes). However, while opening a profile in such wastes and investigating the humipedon, it is easy to find the usual characters of well-known humus horizon references. It is then easy to classify the humipedon even if it has been strongly disturbed by Man (Figs. 17 and 18 ). In order to better describe this humipedon we invite readers to use World Reference Base (WRB) or Soil Taxonomy (ST) qualifiers, as for soil profiles (Soil Survey Staff, 2014; IUSS Working Group WRB, 2015). The more common WRB and ST qualifiers used to describe urban humipedons are reported in Appendix A. Examples of names are also provided.

Note that according to our classification Edifisols (Charzyński et al., 2015) are also Agro humus systems.

A special chapter (Humusica 2, article 16) is dedicated to artificial man-made humipedons which cannot be easily reported to natural references. They are called Techno humus systems.

\section{Classification of Agro humus systems and forms}

\subsection{Terrestrial Agro systems}

By observing all Agro humus systems, it is possible to state that they may be amenable to two main natural systems, corresponding to more or less modified or poorly zoogenic Mull (without $\mathrm{OH}$ horizons) or Amphi (with $\mathrm{OH}$ horizons), called Agro Mull and Agro Amphi, respectively. Dynamically, an Agro Mull is often a natural Mull "transformed by Man for agricultural purpose" with 
topsoil still similar to Mull (generally an impoverished Mull, with lesser biodiversity and a rich content in N).

Agro Mull are anthropogenic humus systems with presence in the A horizon of living earthworms or their casts (except in frozen or desiccated soil); uniformity of the A horizon, as in case of high earthworm activity; in the A horizon, very gradual vertical change in colour, organic matter content, texture, structure or other general characters; absence of any $\mathrm{OH}$ horizon.

The presence of specific anthropogenic A horizons allows to identify Agro Mull or Agro Amphi forms, names of which are composed as follows: 1) structural type (as prefix, in small letters, example: if biomacrostructure then the prefix is biomacro), followed by 2) name of the anthropogenic humus system (with first letter in capital, ex. Agro) then followed by 3 ) name of corresponding natural humus system (first letter in capital, ex. Mull):

- biomacro A (amaA) = biomacro Agro Mull (Figs. 3, 4a, Figs. 13a-c and Fig. 17);

- biomeso A (ameA) = biomeso Agro Mull (Figs. 3, 4b, Figs. 12b-d);

- biomicro $A(a m i A)$ = biomicro Agro Mull (Figs. 5 a and b, Figs. 10a-d);

- massive $(a m s A)=$ massive Agro Mull (Figs. 11, Figs. 8a-f, Fig. 15e).

Agro Amphi are anthropogenic humus system with remaining layers of organic matter on the topsoil:

- biomacro $\mathrm{A}(\mathrm{amaA})+$ organic remains $(\mathrm{OH}$ horizon $)=$ biomacro Agro Amphi

- biomeso $A(a m e A)+$ organic remains $(O H$ horizon) = biomeso Agro Amphi

- biomicro $\mathrm{A}(\mathrm{ami} \mathrm{A})+$ organic remains $(\mathrm{OH}$ horizon $)=$ biomicro Agro Amphi

- massive $\mathrm{A}(\mathrm{ams} \mathrm{A})$ +organic remains (OH horizon) = massive Agro Amphi (Fig. 18).

In the last years, for preventing a worrying ingoing process of soil erosion, many European vineyard farmers managed interline grassy areas or deposited pruning remains on the ground as a mulch. It is possible to observe how a new thin $(5 \mathrm{~cm})$ living soil is forming little by little over a poorly zoogenic amaA horizon (Figs. 19a and b). Actually this soil may be classified as biomicro Agro Moder. A biomicro $A$ horizon is clearly expressed even if at the bottom of the living layer a massive grey $A$ horizon is still present.

Hydro intergrades are possible and recognizable by hydromorphic features in the A horizon. Their name is formed by adding Hydro to the name of the humus form (ex. Hydro biomacro Agro Mull, corresponding to an Agro Mull with amagA, Fig. 20a).

\subsection{Histic agro systems}

In periodically submerged soil cultures (e.g., rice crops) the soil may be amenable to terrestrial Hydro Agro Mull or to histic Agro Anmoor. This matter is still under investigation, despite the worldwide importance of rice crops for the food supply of mankind, and we here report only an example of a histic topsoil in an Italian rice crop (Fig. 20b). An important character that often allows separating histic from terrestrial Agro systems is the presence in the former group of a gley mineral 
horizon (or gleyic properties, as defined by IUSS Working Group WRB, 2015), with reduced (bluegrey) iron oxides, overlaid by a diagnostic Anmoor organic-mineral horizon (anA). Semi-aquatic rice grows in paddy fields submerged a few months each year; deep water rice grows in flooded conditions with more than $50 \mathrm{~cm}$ water for at least a month. The amount of water and the duration of the submersion period depend on rice varieties.

Paddy fields are a typical feature of rice farming and can be built in steep hillsides as terraces adjacent to rivers or marshes. They require a great deal of labour and large quantities of water for irrigation. Paddy fields are an important source of atmospheric methane. Draining the paddies and aerating the soil during long periods allows a significant reduction of methane emission. In general, paddy fields and rice soils correspond to Agro Hydro Mull, which turn to anoxic conditions during the submersion season, evolving as a consequence toward Anmoor for a few months. Artificial irrigation, ploughing and levelling with mechanical or animal means, as well as the necessary mineral and organic fertilization, strongly modifies soil development compared to natural Hydro Mull (where water rises by capillarity) or Anmoor (slow, extended periods of submersion and emersion).

An Agro Anmoor corresponds to an anthropogenic humus system with presence of an anA organic-mineral horizon and absence of HF or HM or HS (Fig. 20b).

Epihistic intergrades are possible in the combined presence of terrestrial $(\mathrm{gA}, \mathrm{gOH})$ and histic (anA, HS) horizons (ex. Epihistic Agro Anmoor, with superposed gA and anA, anA thicker than gA and lying on a reduced mineral basement).

\section{Conclusion}

We hope having convinced readers that describing and classifying agroecosystem humipedons is much easier than expected. The use of natural references found in nearby forests and natural grasslands seems a profitable tool for (i) the comparative description of topsoil structures, and (ii) as a target to be achieved when trying to improve the biological quality of agricultural and other anthropogenic soils. Crop fields, and to a lesser extent pastures and meadows, originate from natural or semi-natural environments which have been historically disturbed by mechanical (tillage), chemical (fertilizers, pesticides) and biological (vegetation change and seasonal collapse, grazing) practices (Green, 1989). However, these practices do not kill soil life, in particular the activity of ecosystem engineers (e.g., earthworms, enchytraeids), although in a constant state-of-change due to disturbances, is still visible (up to a certain threshold) in the form of aggregates and burrows, and continue to play a leading role in the maintenance of soil fertility through its control of soil microflora and other ecosystem services (Crotty et al., 2016; Fusaro, 2015; Van der Wal and De Boer, 2017; Wood et al., 2015; Lavelle et al., 2006). Litter is absent and cannot be used as a visual clue for characterizing the rate of recycling of organic matter, contrary to forests, heathlands and natural grasslands (Jenny et al., 1949). However, different levels of disturbance generate different structures (from biomacro to massive), which can be easily identified to the naked eye in agroecosystems, and are used in our morpho-functional classification of Agro humus forms and systems. 


\section{Appendix A. Possible WRB and ST qualifiers}

\section{Possible WRB qualifiers (original source IUSS Working Group WRB, 2015)}

The World Reference Base for Soil Resources (IUSS Working Group WRB, 2015) is the international standard taxonomic soil classification system endorsed by the International Union of Soil Sciences (IUSS). It is based mainly on soil morphology as an expression of pedogenesis, with 30 reference groups aggregated in 10 main groups, and a large set of qualifiers used to specify particular soil features. Some of them are listed below, which could be used to characterize anthropogenic humipedons:

- Pretic $=$ with pretic horizon $=$ dark, high content of organic matter and $\mathrm{P}$, low animal activity, high contents of exchangeable $\mathrm{Ca}$ and $\mathrm{Mg}$, with charcoal remnants and/or artefacts, as also observed in Amazonian Dark Earths

- Ekranic: Technic hard material starting within $5 \mathrm{~cm}$ of the soil surface and covering $\geq 95 \%$ of the horizontal extent of the soil

- Urbic: $\geq 35 \%$ of artefacts consisting of rubble and garbage from human settlements

- Linic: A continuous, very slowly permeable to impermeable, constructed geomembrane starting within $100 \mathrm{~cm}$ of the soil surface

- Spolic: $\geq 35 \%$ of artefacts consisting of industrial waste material (mine spoils, dredged sediments, rubble, etc.)

- Garbic: $\geq 35 \%$ of artefacts consisting of organic waste material

\section{Possible Soil Taxonomy subgroup adjectives (original source Soil Survey Staff, 2014)}

The USDA Soil Taxonomy is historically more ancient than WRB (it was firstly issued in 1938) and was conceived for the United States while still in use in many other countries. The main difference with WRB is that it includes climate, not only morphology, in the classification of soils. Some USDA subgroup adjectives are associated to Human Altered Human Transported (HAHT) soils found most often in reclaimed mine lands and building or transportation construction sites:

- Methanogenic: soils with detectable emission of methane or methyl mercaptans; found in landfills or waste-disposal sites; does not include the natural emission of methane from anaerobic environments

- Asphaltic: contains appreciable contents of asphalts; found in areas filled with construction debris or on the top of old impervious surfaces, landfills, and near highway paving works

- Concretic: contains appreciable contents of concrete; found in areas filled with construction debris or on the top of old impervious surfaces, landfills, and near building works 
- Gypsifactic: contains appreciable contents of synthetic gypsum products, often as drywall or flue gas desulfurization gypsum; found in areas filled with construction debris, landfills, and near buildings

- Combustic: contains appreciable contents of coal combustion by-products too heavy to be volatile, including bottom ash or coal slag; found in approved disposal areas, unregulated fill sites, city parks, and gravel-topped roads in urban areas

- Ashifactic: contains appreciable contents of light-weight, coal combustion by-products that are volatile, such as fly ash; typically found in approved disposal sites, unregulated fill sites, or retention ponds near power plants

- Pyrocarbonic: contains appreciable content of light-weight products of pyrolysis such as fuel coke or biochar; typically found in approved disposal sites, unregulated fill sites, retention ponds near power plants, or Terra Preta (Amazonian Dark Earth) soils

- Artifactic: contains $>35 \%$ discrete artefacts $>2 \mathrm{~mm}$ that are both persistent and cohesive; typically found in landfills, fill areas, and transportation corridors

- Pauciartifactic: contains between 15 and 35\% discrete artefacts $>2 \mathrm{~mm}$ that are both persistent and cohesive; typically found in landfills, fill areas, urban areas, construction sites, and transportation corridors

- Dredgic: contains finely-stratified ( $<5 \mathrm{~mm}$ thick) layers of dredged or irrigated sediments; found in anthropogenic landforms near dredged waterways and in irrigated agricultural fields flooded with diverted stream water

- Spolic: contains Human Transported Material (HTM); found mainly in anthropogenic landforms, clean fill areas, and artificially-landscaped areas

- Araric: contains Human Modified Material (HAM); found mainly in intensely-managed agricultural fields, burial grounds, excavated borrow and mine pits and transportation corridors, and flood-irrigated rice and fish production areas

\section{Examples of names with WRB or ST qualifiers}

We suggest citing the qualifier (or adjective) before the name of the humus system and to set between brackets WRB for Word Reference Base or ST for Soil Taxonomy. A qualifier with the same name may have a different signification in each reference.

- Urbic (WRB) Agro Mull or more precisely, if possible, Urbic (WRB) biomeso Agro Mull

- Spolic (WRB) Agro Mull or Spolic (WRB) massive Agro Mull

- Garbic (WRB) Agro Mull or Garbic (WRB) biomacro Agro Mull

- Concretic (ST) Agro Anmoor

- Methanogenic (ST) Agro Mull or Methanogenic (ST) biomicro Agro Mull

\section{References}


Awadhwal, N.K., Thierstein, G.E., 1985. Soil crust and its impact on crop establishment: a review. Soil Tillage Res. 5, 289-302.

Balesdent, J., Chenu, C., Balabane, M., 2000. Relationship of soil organic matter dynamics to physical protection and tillage. Soil Tillage Res. 53, 215-230.

Barratt, B.C., 1967. Differences in humus forms and their microfabrics induced by long-term topdressings in hay fields. Geoderma 1, 209-227.

Brittain, C.A., Vighi, M., Bommarco, R., Settele, J., Potts, S.G., 2010. Impacts of a pesticide on pollinator species richness at different spatial scales. Basic Appl. Ecol. 11, 106-115.

Carter, M.R., 1991. Evaluation of shallow tillage for spring cereals on a fine sandy loam. II. Soil physical, chemical and biological properties. Soil Tillage Res. 21, 37-52.

Chan, K.Y., 2001. An overview of some tillage impacts on earthworm population abundance and diversity: implications for functioning in soils. Soil Tillage Res. 57, 179-191.

Charzyński, P., Hulisz, P., Bednarek, R., Piernik, A., Winkler, M., Chmurzyński, M., 2015. Edifisols: a new soil unit of technogenic soils. J Soils Sediments 15, 1675-1686.

Crotty, F.V., Fychan, R., Sanderson, R., Rhymes, J.R., Bourdin, F., Scullion, J., Marley, C.L., 2016. Understanding the legacy effect of previous forage crop and tillage management on soil biology, after conversion to an arable crop rotation. Soil Biol. Biochem. 103, 241-252.

De Nicola, C., Zanella, A., Testi, A., Fanelli, G., Pignatti, S., 2014. Humus forms in a Mediterranean area (Castelporziano Reserve, Rome, Italy): classification, functioning and organic carbon storage. Geoderma 235/236, 90-99.

Eisenhauer, N., Maraun, S., Scheu, S., 2008. Assessment of anecic behavior in selected earthworm species: effects on wheat seed burial, seedling establishment, wheat growth and litter incorporation. Appl. Soil Ecol. 38, 79-82.

El Titi, A., Ipach, U., 1989. Soil fauna in sustainable agriculture: results of an integrated farming system at Lautenbach, F.R.G. Agric. Ecosyst. Environ. 27, 561-572.

Ernst, G., Emmerling, C., 2009. Impact of five different tillage systems on soil organic carbon content and the density biomass, and community composition of earthworms after a ten year period. Eur. J. Soil Biol. 45, 247-251.

FAO, 2006. Guidelines for Soil Description, $4^{\text {th }}$ ed. Food and Agriculture Organization of the United Nations, Rome. http://www.fao.org/docrep/019/a0541e/a0541e.pdf (Accessed 30 June 2017).

Fusaro, S., 2015. Evaluation, maintenance and improvement of biodiversity for environmental protection and crop. Doctorate Thesis, Università degli Studi di Padova.

Geiger, F., Bengtsson, J., Berendse, F., Weisser, W.W., Emmerson, M., Morales, M.B., Ceryngier, P., Liira, J., Tscharntke, T., Winqvist, C., Eggers, S., Bommarco, R., Pärt, T., Bretagnolle, V., Plantegenest, M., Clement, L.W., Dennis, C., Palmer, C., Oñate, J.J., Guerrero, I., Hawro, V., 
Aavik, T., Thies, C., Flohre, A., Hänke, S., Fischer, C., Goedhart, P.W., Inchausti, P., 2010. Persistent negative effects of pesticides on biodiversity and biological control potential on European farmland. Basic Appl. Ecol. 11, 97-105.

Green, B.H., 1989. Agricultural impacts on the rural environment. J. Appl. Ecol. 26, 793-802.

Hamza, M.A., Anderson, W.K., 2005. Soil compaction in cropping systems: a review of the nature, causes and possible solutions. Soil Tillage Res. 82, 121-145.

Holmstrup, M., 2001. Sensitivity of life history parameters in the earthworm Aporrectodea caliginosa to small changes in soil water potential. Soil Biol. Biochem. 33, 1217-1323.

IUSS Working Group WRB, 2015. World Reference Base for Soil Resources 2014, Update 2015: International Soil Classification System for Naming Soils and Creating Legends for Soil Maps. Food and Agriculture Organization of the United Nations, Rome. http://www.fao.org/3/ai3794e.pdf (Accessed 30 June 2017).

Jenny, H., Gessel, S.P., Bingham, F.T., 1949. Comparative study of decomposition rates of organic matter in temperate and tropical regions. Soil Sci. 68, 419-432.

Jouquet, P., Dauber, J., Lagerlöf, J., Lavelle, P., Lepage, M., 2006. Soil invertebrates as ecosystem engineers: intended and accidental effects on soil and feedback loops. Appl. Soil Ecol. 32, 153-164.

Kibblewhite, M.G., Ritz, K., Swift, M.J., 2008. Soil health in agricultural systems. Phil. Trans. R. Soc. B $363,685-701$.

Lavelle, P., Decaëns, T., Aubert, M., Barot, S., Blouin, M., Bureau, F., Margerie, P., Mora, P., Rossi, J.P., 2006. Soil invertebrates and ecosystem services. Eur. J. Soil Biol. 42, S3-S15.

Lavelle, P., 1988. Earthworm activities and the soil system. Biol. Fertil. Soils 6, 237-251.

Mäder, P., Fließbach, A., Dubois, D., Gunst, L., Fried, P., Niggli, U., 2002. Soil fertility and biodiversity in organic farming. Science 296, 1694-1697.

Pélosi, C., Barot, S., Capowiez, Y., Hedde, M., Vandenbulcke, F., 2014. Pesticides and earthworms: a review. Agron. Sustain. Develop. 34, 199-228.

Pélosi, C., Toutous, L., Chiron, F., Dubs, F., Hedde, M., Muratet, A., Ponge, J.F., Salmon, S., Makowski, D., 2013. Reduction of pesticide use can improve earthworm populations in wheat crops in a European temperate region. Agr. Ecosyst. Environ. 181, 223-230.

Ponge, J.F., Pérès, G., Guernion, M., Ruiz-Camacho, N., Cortet, J., Pernin, C., Villenave, C., Chaussod, R., Martin-Laurent, F., Bispo, A., Cluzeau, D., 2013. The impact of agricultural practices on soil biota: a regional study. Soil Biol. Biochem. 67, 271-284.

Six, J., Elliott, E.T., Paustian, K., 1999. Aggregate and soil organic matter dynamics under conventional and no-tillage systems. Soil Sci. Soc. Am. J. 63, 1350-1358. 
Six, J., Elliott, E.T., Paustian, K., 2000. Soil macroaggregate turnover and microaggregate formation: a mechanism for $\mathrm{C}$ sequestration under no-tillage agriculture. Soil Biol. Biochem. 32, 20992103.

Soil Survey Staff, 2014. Keys to Soil Taxonomy by Soil Survey Staff, $12^{\text {th }}$ ed. United States Department of Agriculture, Natural Resources Conservation Service, Washington, DC. https://www.nrcs.usda.gov/wps/PA NRCSConsumption/download?cid=stelprdb1252094\&ex $\mathrm{t}=\mathrm{pdf}$ (Accessed 30 June 2017).

Stoate, C., Boatman, N.D., Borralho, R.J., Rio Carvalho, C., De Snoo, G.R., Eden, P., 2001. Ecological impacts of arable intensification in Europe. J. Environ. Manag. 63, 337-365.

Tejada, M., Hernandez, M.T., Garcia, C., 2009. Soil restoration using composted plant residues: effects on soil properties. Soil Tillage Res. 102, 109-117.

Topoliantz, S., Ponge, J.F., Viaux, P., 2000. Earthworm and enchytraeid activity under different arable farming systems, as exemplified by biogenic structures. Plant Soil 225, 39-51.

Van der Wal, A., De Boer, W., 2017. Dinner in the dark: illuminating drivers of soil organic matter decomposition. Soil Biol. Biochem. 105, 45-48.

Wood, S.A., Karp, D.S., DeClerck, F., Kremen, C., Naeem, S., Palm, C.A., 2015. Functional traits in agriculture: agrobiodiversity and ecosystem services. Trends Ecol. Evol. 30, 531-539. 


\section{Figure captions}

Fig. 1. Structureless massive material. a) Compact material the pore network of which is limited to some poorly developed root channels. The structure cannot be broken up in aggregates by hand. No faunal excrements are visible; b) For comparison, a picture of a compact surficial "crust" in an agricultural soil (photograph S. Topoliantz).

Fig. 2. Structureless single grain material is often present in sandy soils (here under dune grass stem bases and under a biomicrostructured A horizon). In this context, the process of formation of an organic-mineral A horizon is very slow and mainly due to snails and little arthropods. On this photograph the A horizon occupies the first top centimetre of a grey soil. Under this thin layer, in the soil explored by grass roots, biogenic dark-coloured peds are less than $10 \%$ of the volume estimated by naked eye. This second clearer layer corresponds to structureless single grain material.

Fig. 3. Well-individualized round and more or less eroded (aged) earthworm droppings (photograph S. Topoliantz).

Fig. 4. a) Left, anecic and b) Endogeic earthworm droppings (photographs S. Topoliantz).

Fig. 5. Very fine granular material. a) Left, this well-aerated structure is made of small wellindividualized aggregates, resulting from the defecating activity of small endogeic worms or big enchytraeids; b) For comparison, droppings (clustered round pills, 30-50 $\mu \mathrm{m}$ each) and galleries of enchytraeids filling an earthworm burrow lumen with biomicrostructured material (photographs S. Topoliantz).

Fig. 6. Field digital scale and two sieves for estimating the aggregate size distribution. Fine granular material (or larger aggregates or soil blocks, which are set apart) are refused by the first (top) sieve $(4 \mathrm{~mm})$, while very fine granular material is refused by the second sieve $(1 \mathrm{~mm})$ and finer material passes through it. When collected in three calibrated plastic glass vials and weighed, these three parts of the sample give an estimate of the volume of size-calibrated materials that help in determining the soil diagnostic horizon. The observation of each calibrated sample of soil with a 10X magnifying lens is also strongly suggested, in order to detect biological features of the aggregates (e.g., rounded edges, amalgamated structures, organic matter embodiments).

Fig. 7. Anthropogenic diagnostic horizons and composing materials. Blue line: structureless massive material; dashed green line: fine and very fine granular or biomesostructured materials; red line: granular, fine granular or biomacrostructured materials. Structureless massive (anthropogenic) and nonzoogenic massive materials cannot be distinguished the one from the other. (For interpretation of the references to colour in this figure legend, the reader is referred to the web version of this article).

Fig. 8. Anthopogenic poorly zoogenic massive A horizon (amaA). The ploughed soil is made of large peds (a); when applying moderate to strong pressure with fingers, the soil sample is progressively broken up into finer artificial units. No zones of weakness are detectable in the 
mass. Large blocks can be penetrated by disconnected earthworm burrows or root channels (b); even when the soil has passed through a rotating blade (c), it is possible to see that aggregates are not of biological origin (no round shapes as in Figures 3, 4 and 5) and show a slight "marbled" colour, typical of anoxic conditions (d); the dry soil is very hard to cut; when humid it can be cut like a cheese, and at the bottom some earthworms are visible (e); predators of insect larvae and earthworms may be present, too, like small geophilic centipedes (f).

Fig. 9. Anthropogenic diagnostic horizons and composing materials. Blue line: Structureless single grained material and/or Very fine granular material; green line: Fine and Very fine granular or mesostructured materials; red line: Granular, Fine granular or macrostructured materials. Small sized $(\leq 1 \mathrm{~mm})$, structureless single-grained material generally mixed with biological Very fine granular material.

Fig. 10. Anthropogenic biomicrostructured A horizon. Tender soil in which a blade easily opens a profile (a); the ploughed field (b) aside a more natural environment (managed forest); a crust may form at the soil surface (c) during a dry period following rain (clay crusts form instead on amsA horizons); the largest aggregates (d) have a very weak coherence and break up very easily between fingers.

Fig. 11. Natural humus form intergrade between Dysmull and Hemimoder, in the forest just aside the ploughed field of Figure 10b. The structure of the A horizon (a) is similar to that of the ploughed field (Figs. 10a and d), but in the natural situation the soil shows the typical superposition of organic and organic-mineral horizons (b). The anthropic pozsgA pictured in Figure $10 \mathrm{~d}$ was manured every year and shows how a farmer can sustain a living soil which remains poorer in biogenic structures than its natural version but if regularly fed can grow a good crop.

Fig. 12. Examples of anthropogenic biomesostructured $A$ horizons (ameA). A living soil is rarely anoxic. A lot of cracks and holes are present at the soil surface (a) even after a week of rainy weather $(20 \mathrm{~mm})$; the same soil returned with a blade (b) shows a well-structured living soil easily fragmented in round fine aggregates. A biomesostructured soil is easy to work even if dry (c) and fragments itself in small aggregates when turned up (d).

Fig. 13. Anthropogenic biomacrostructured $A$ horizon (amaA). Aggregates are more or less aged earthworm faeces. Living earthworms are very common (a, b, c). Aggregates are rounded and made of smaller rounded aggregates (which is not the case in poorly zoogenic massive horizons). In the large peds it is easy to notice a lot of lines of weakness (cracks). Taking a photograph with flash light $(a, c)$ may hide relief and number of aggregates, which are better revealed with sun light (b). Agripolis Campus, University of Padua, Italy.

Fig. 14. Comparing anthropogenic and natural structures. a) anthropogenic zoogenic and poorly zoogenic structures; b) natural equivalent structures. Intensification of exploitation may induce strong impoverishment and genesis of non-zoogenic structures, which in natural context correspond to harsh climate or soil conditions. 
Fig. 15. Example of soil in a conventional crop field in Venetian province (Italy). a), b) and c) the field a day after rotary tillage; d) formation of a crust after heavy rain followed by a sunny day; e) massive material at a depth of more than $20 \mathrm{~cm}$, deposited on a spade.

Fig. 16. The soil in a parcel manured with compost and not ploughed for 7 years. The starting soil was equivalent to the one reported in Figure 13. Agripolis Campus, University of Padua, Italy.

Fig. 17. Biomacro Agro Mull in a home organic garden (photograph J.F. Ponge).

Fig. 18. Urban soil under a tree in a street of Paris. Dark organic horizons occupy the first $5 \mathrm{~cm}$, gradually passing to a heterogeneous brown amaA horizon, lying on an ochric Bw horizon. This humipedon can be classified as a massive Agro Amphi.

Fig. 19. a) Soil profile (a) in a vineyard of the Rotaliana plain (Trentino, Italy). By magnifying the topsoil (b), it is possible to see that the poorly zoogenic amaA horizon is revitalized in the upper part of the profile (first $5 \mathrm{~cm}$ ) by grass development and deposition of pruning remains. The operation has generated a thin massive Agro Amphi, which will probably evolve toward an Agro Mull within a few years (photographs G. Sartori).

Fig. 20. a) Hydro Agro Mull; b) Agro Anmoor in a rice crop. Both profiles show a mineral horizon with gleyic properties (reductive hydromorphic grey mineral basement) and an organic-mineral hydromorphic amagA horizon at the top. The second profile, classified as Agro Anmoor, shows a buried (between 20 and $45 \mathrm{~cm}$ ) organic-mineral anA horizon thicker than the overlying gA horizon (photographs A. Andreetta). 


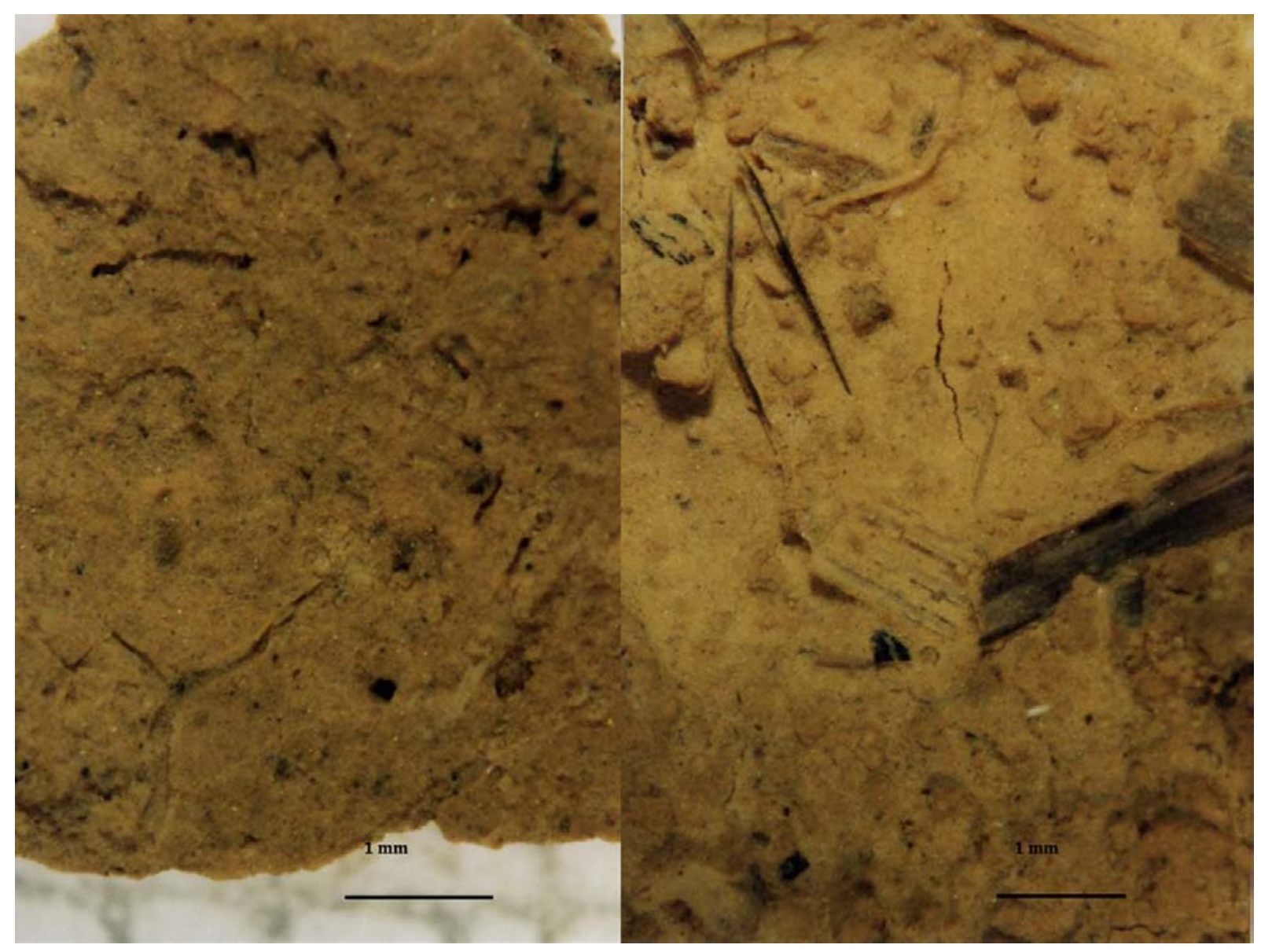

Fig. 1 


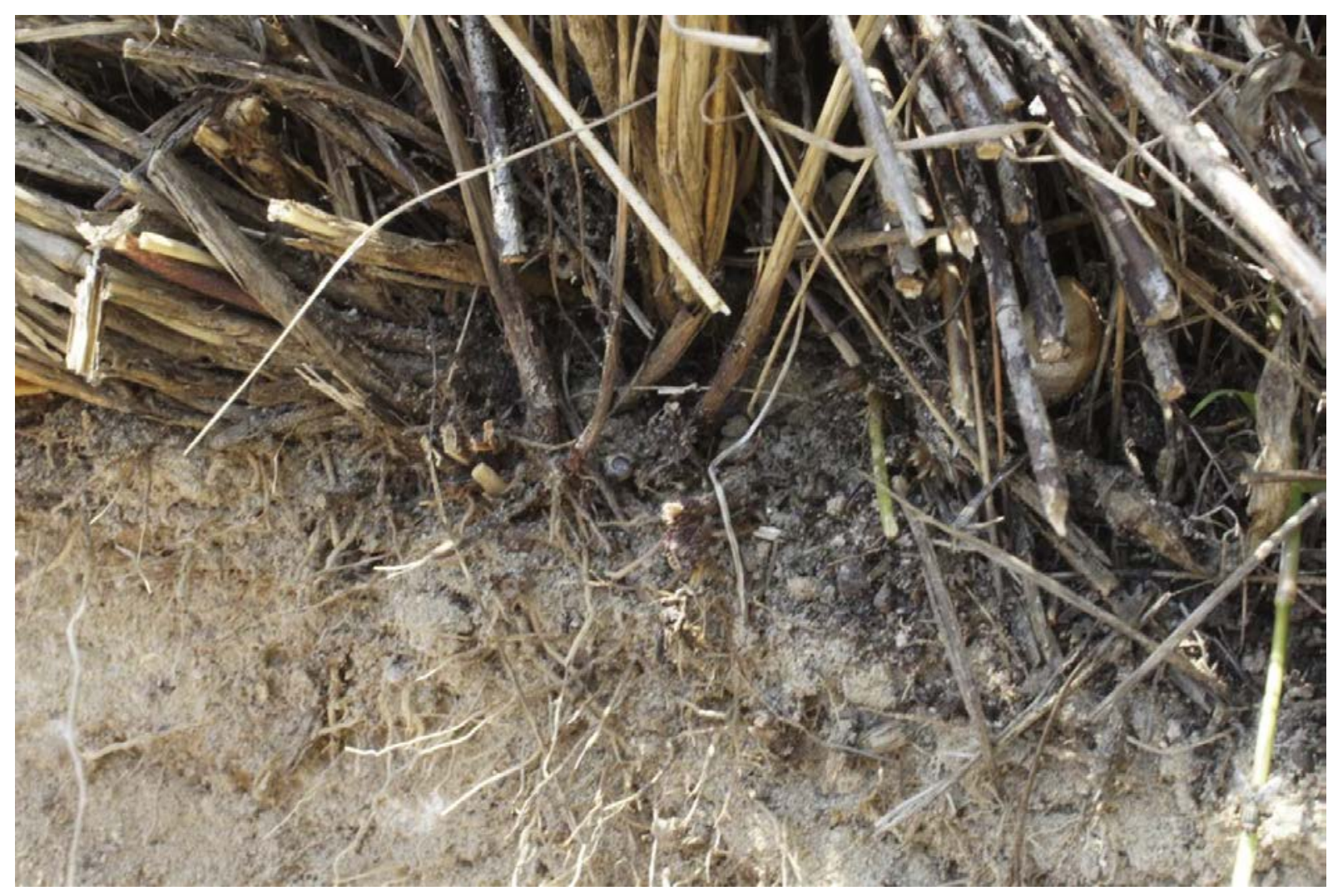

Fig. 2 


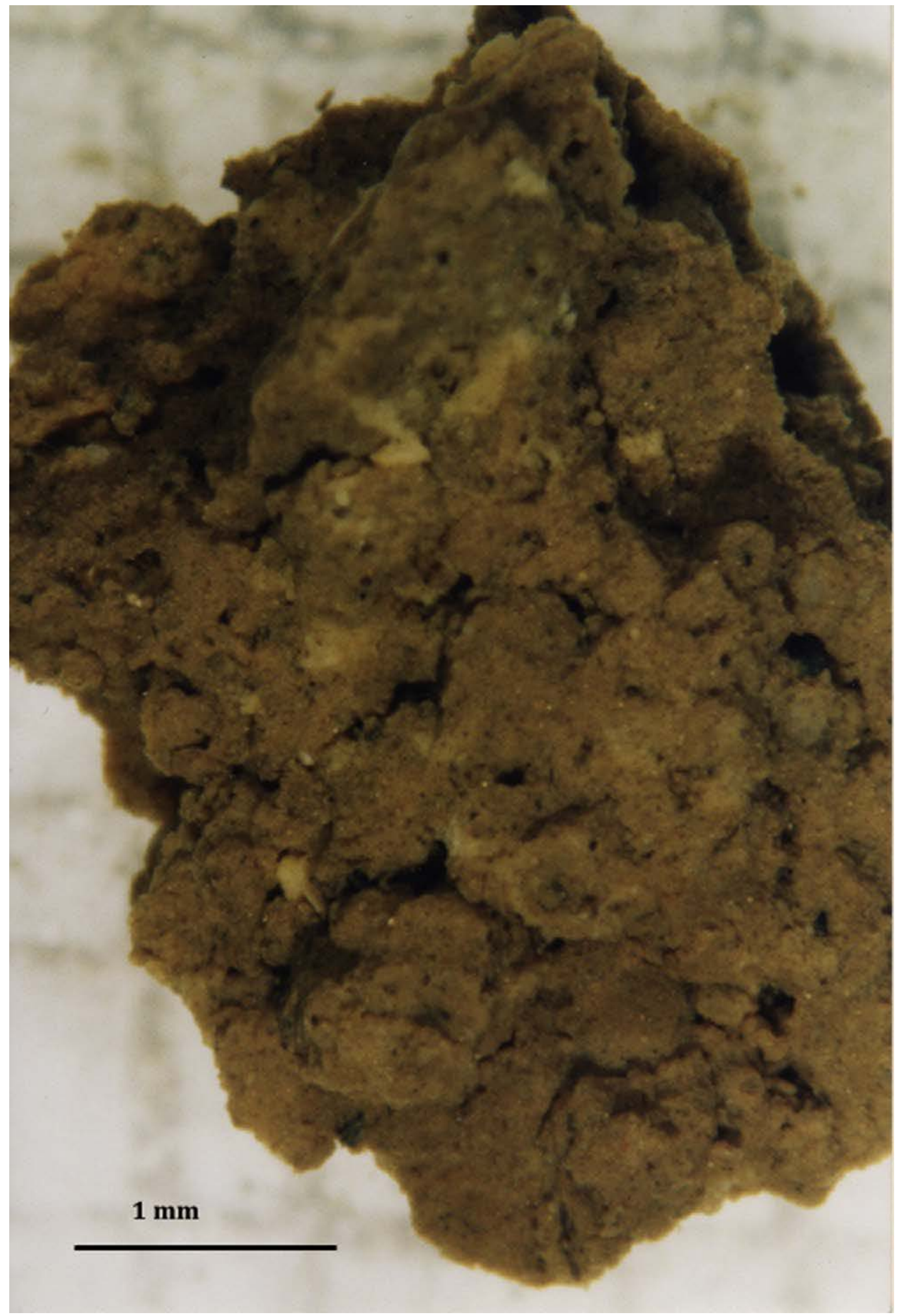

Fig. 3 


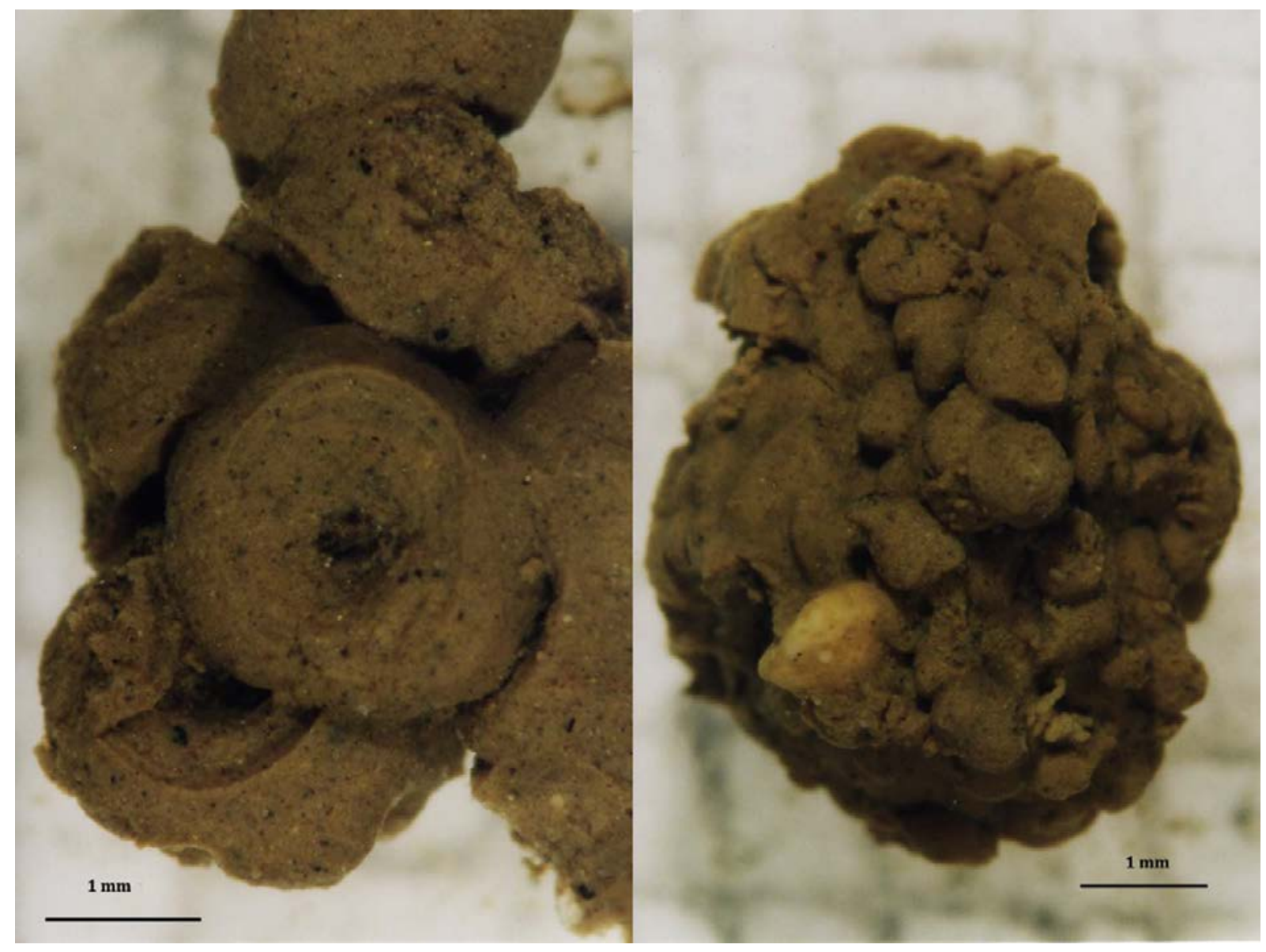

Fig. 4 


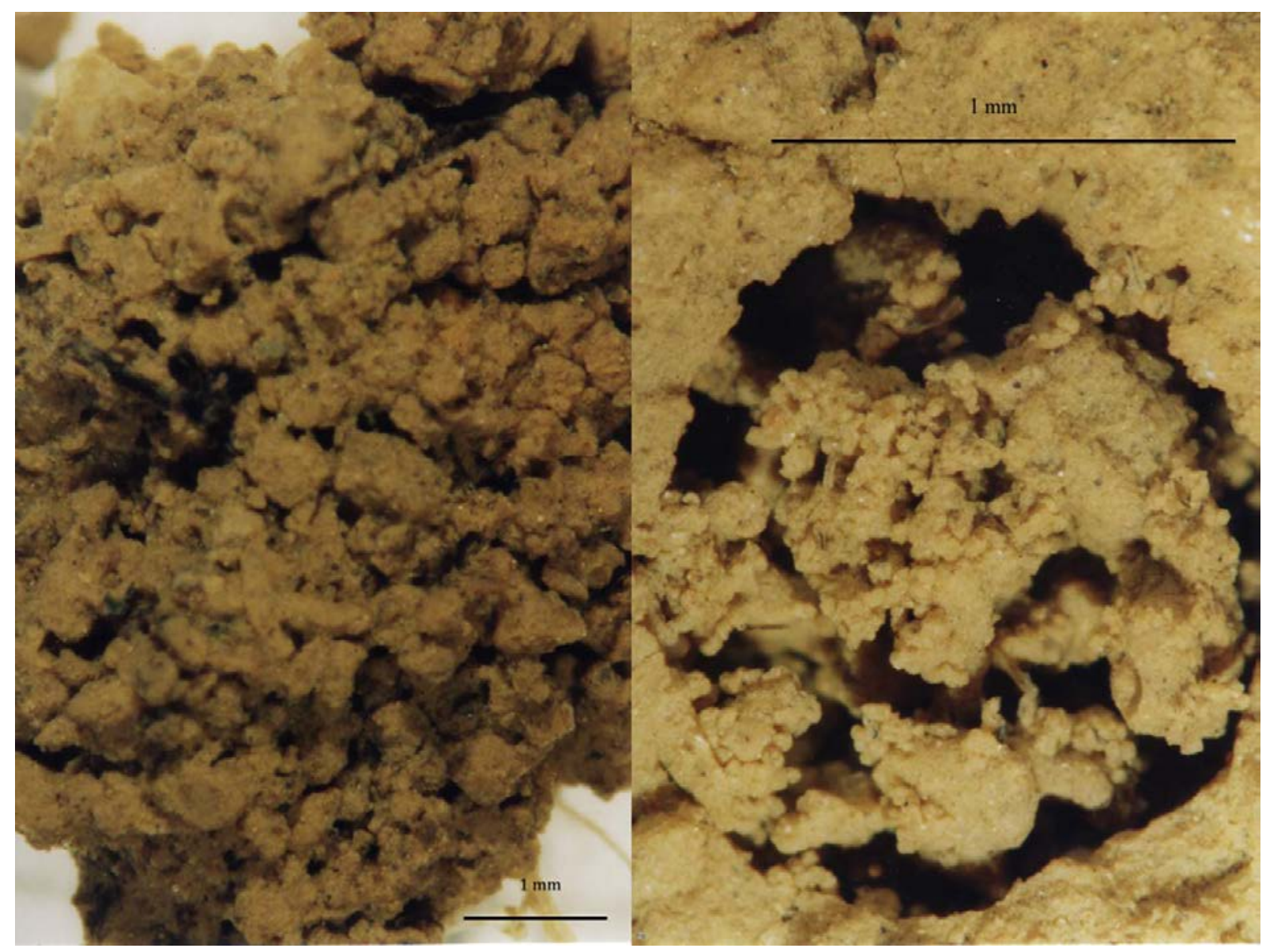

Fig. 5 


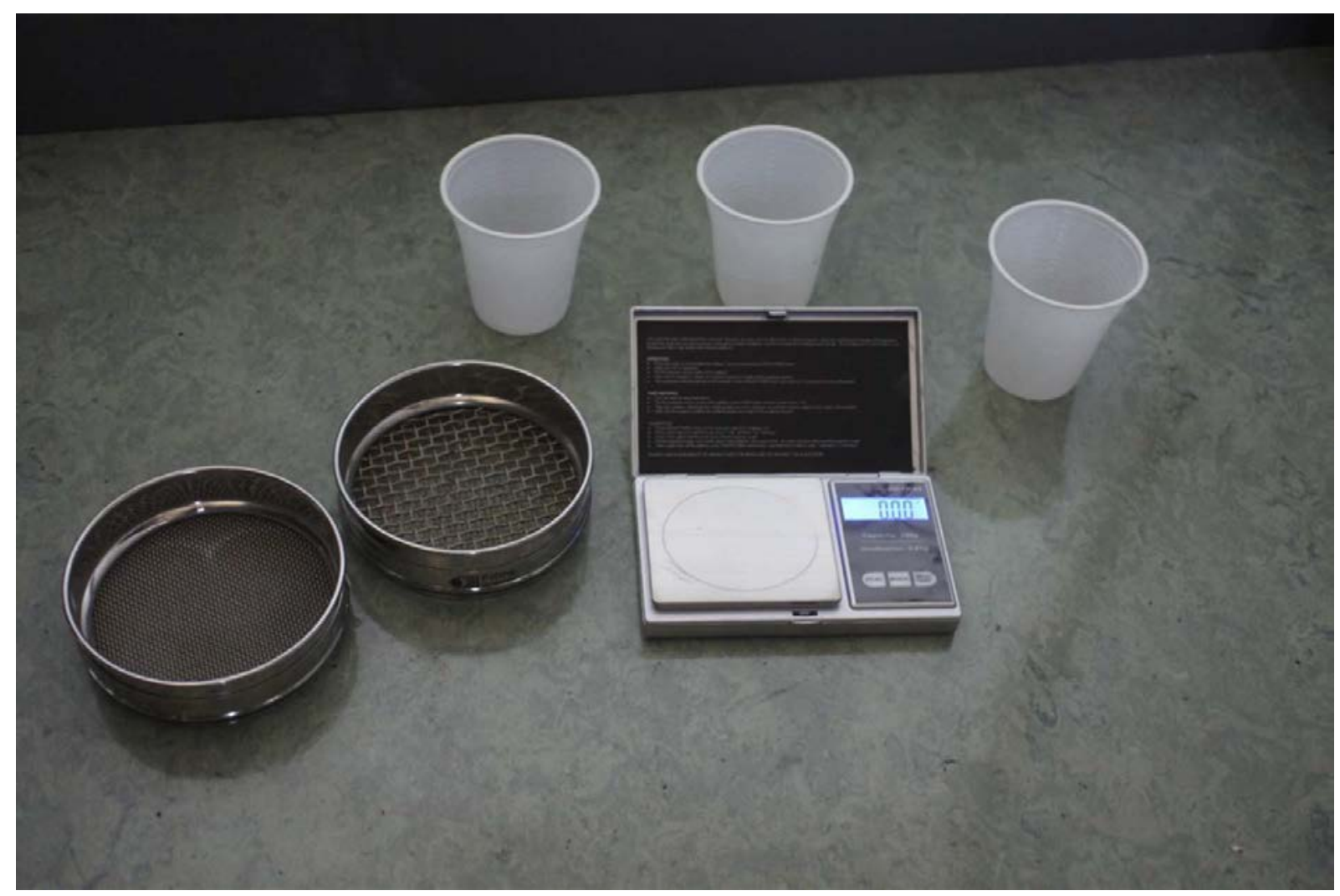

Fig. 6 


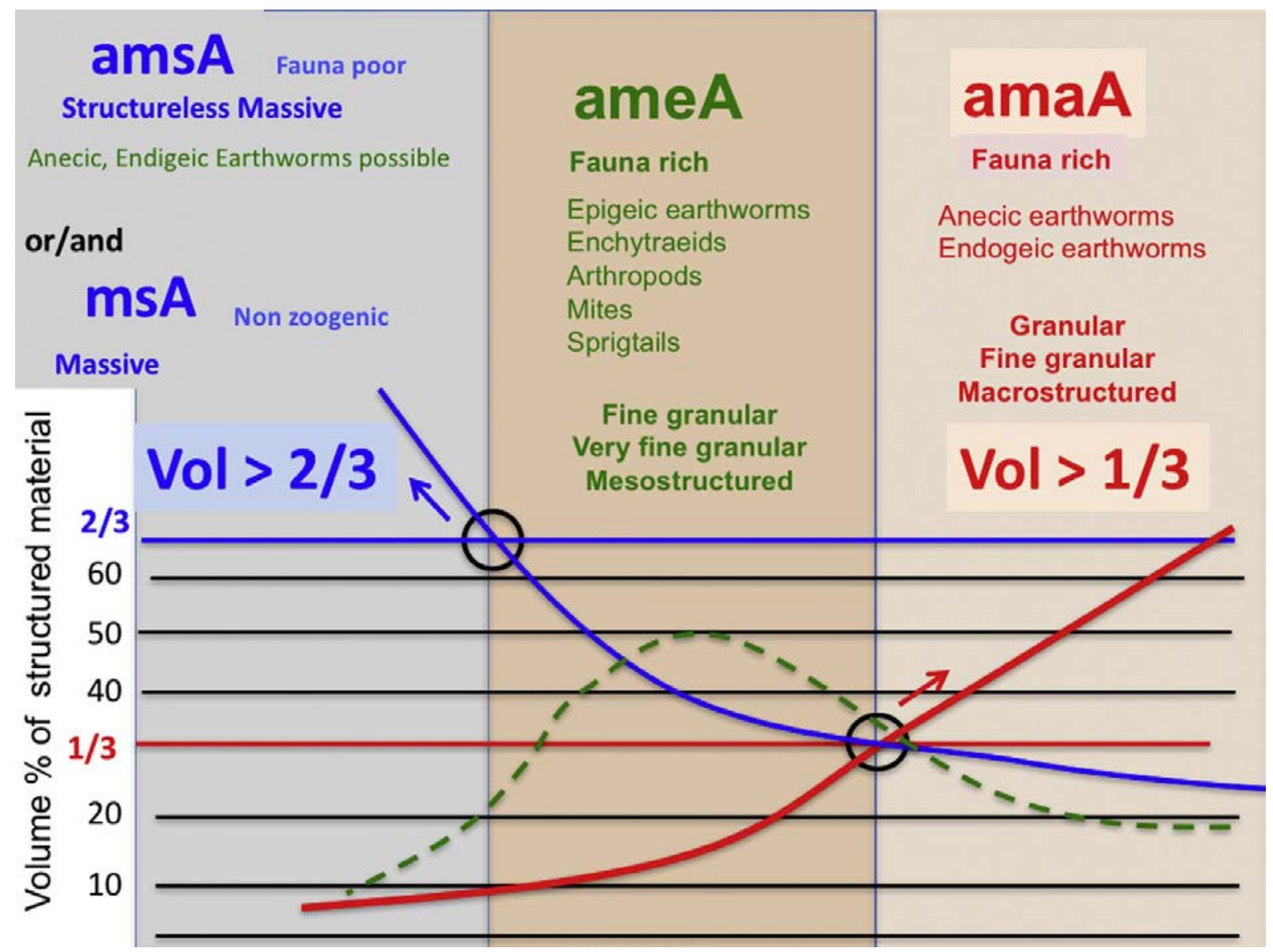

Fig. 7 

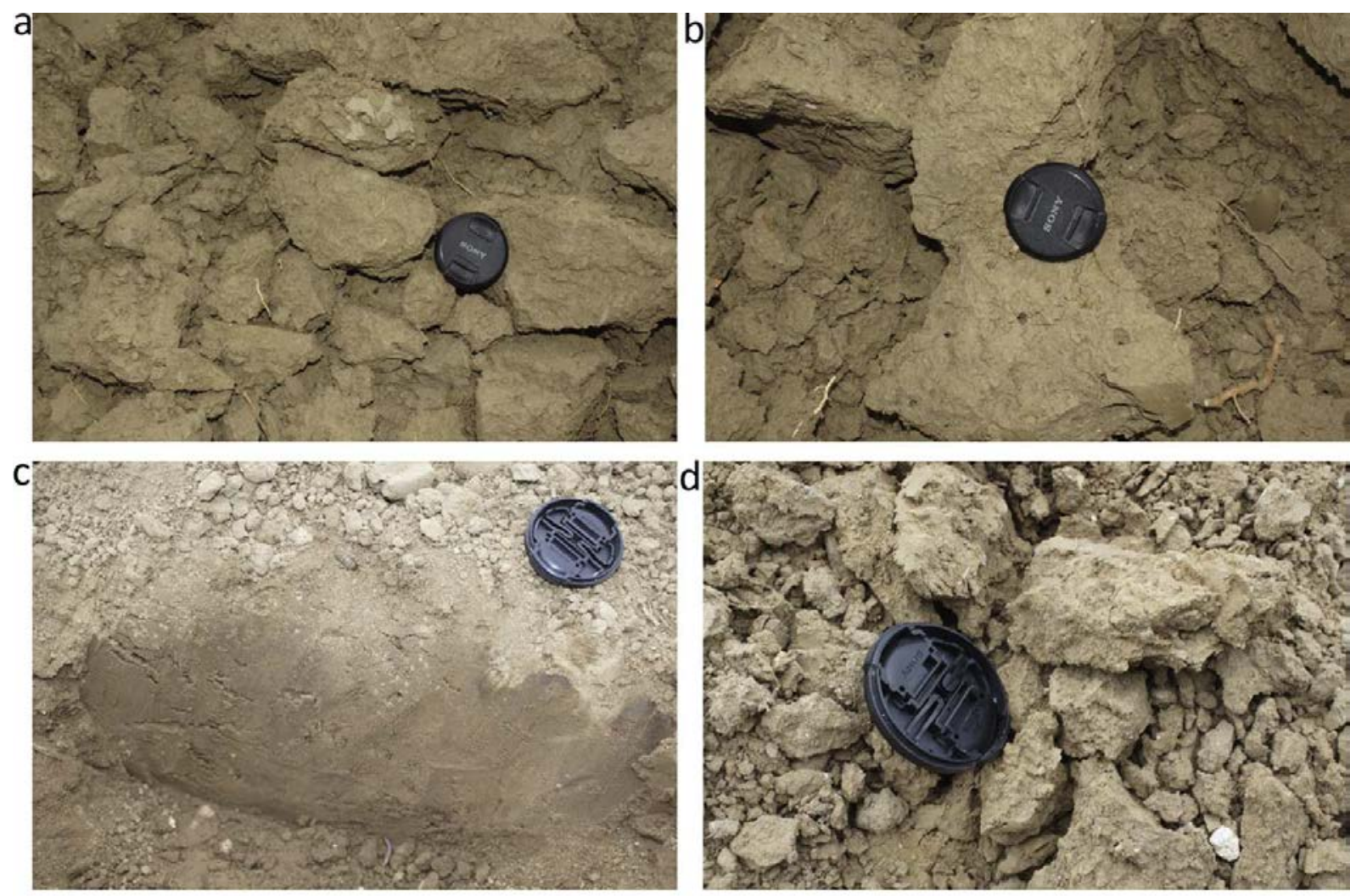

e
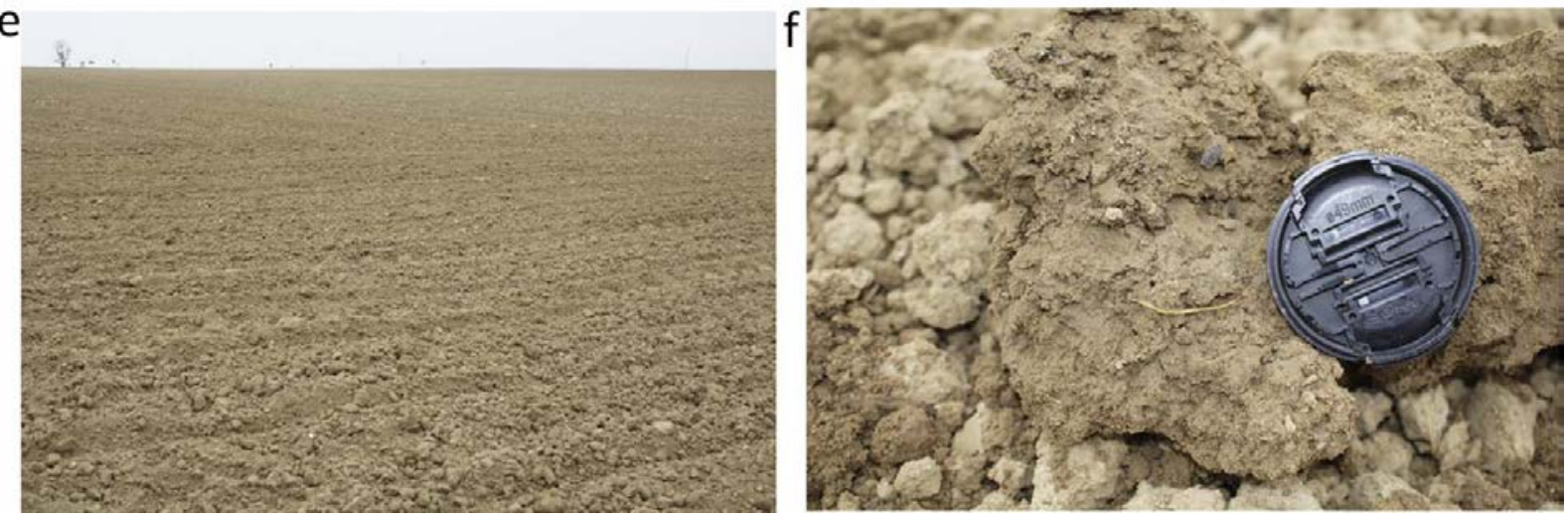

Fig. 8 


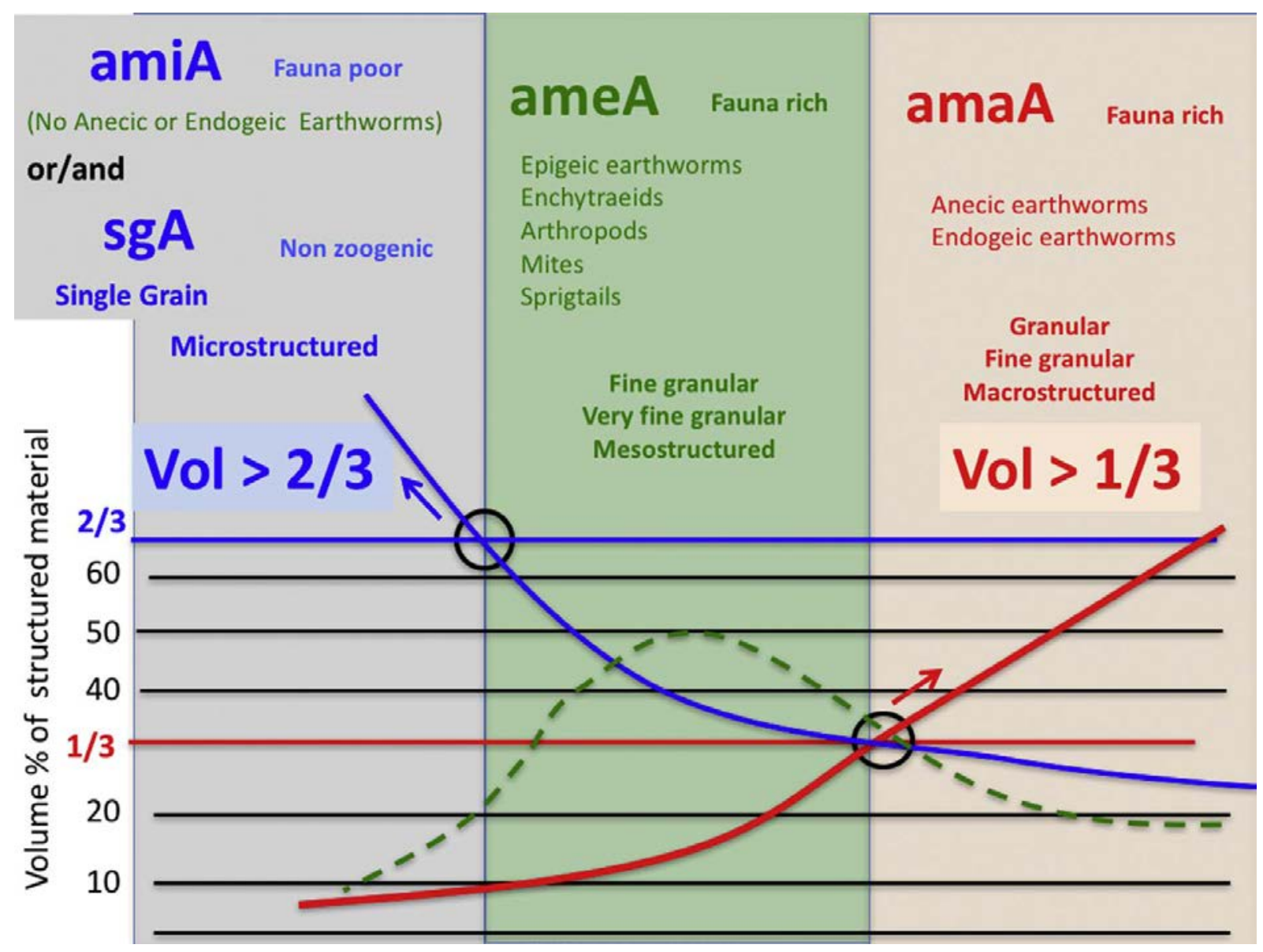

Fig. 9 

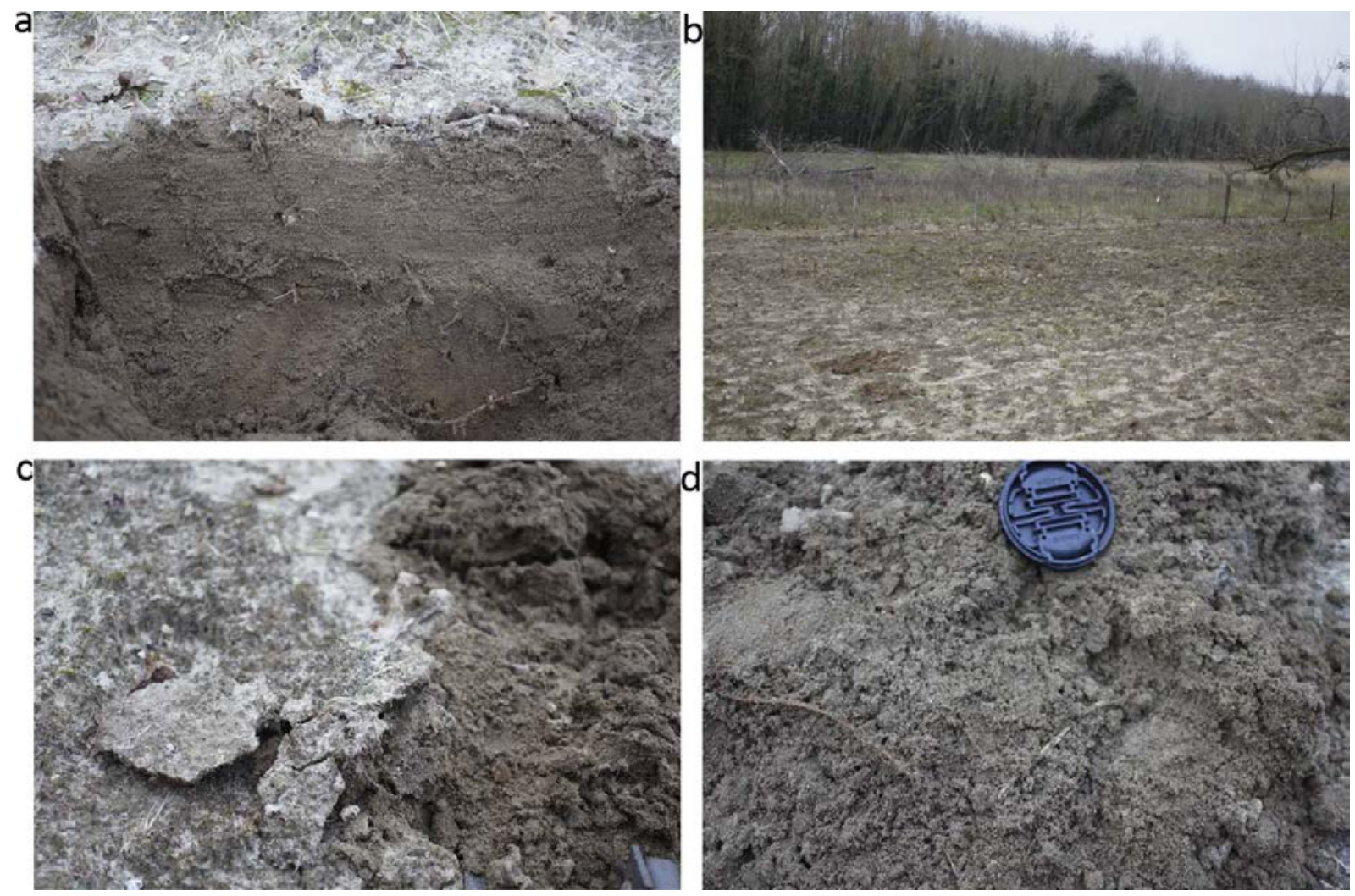

Fig. 10 

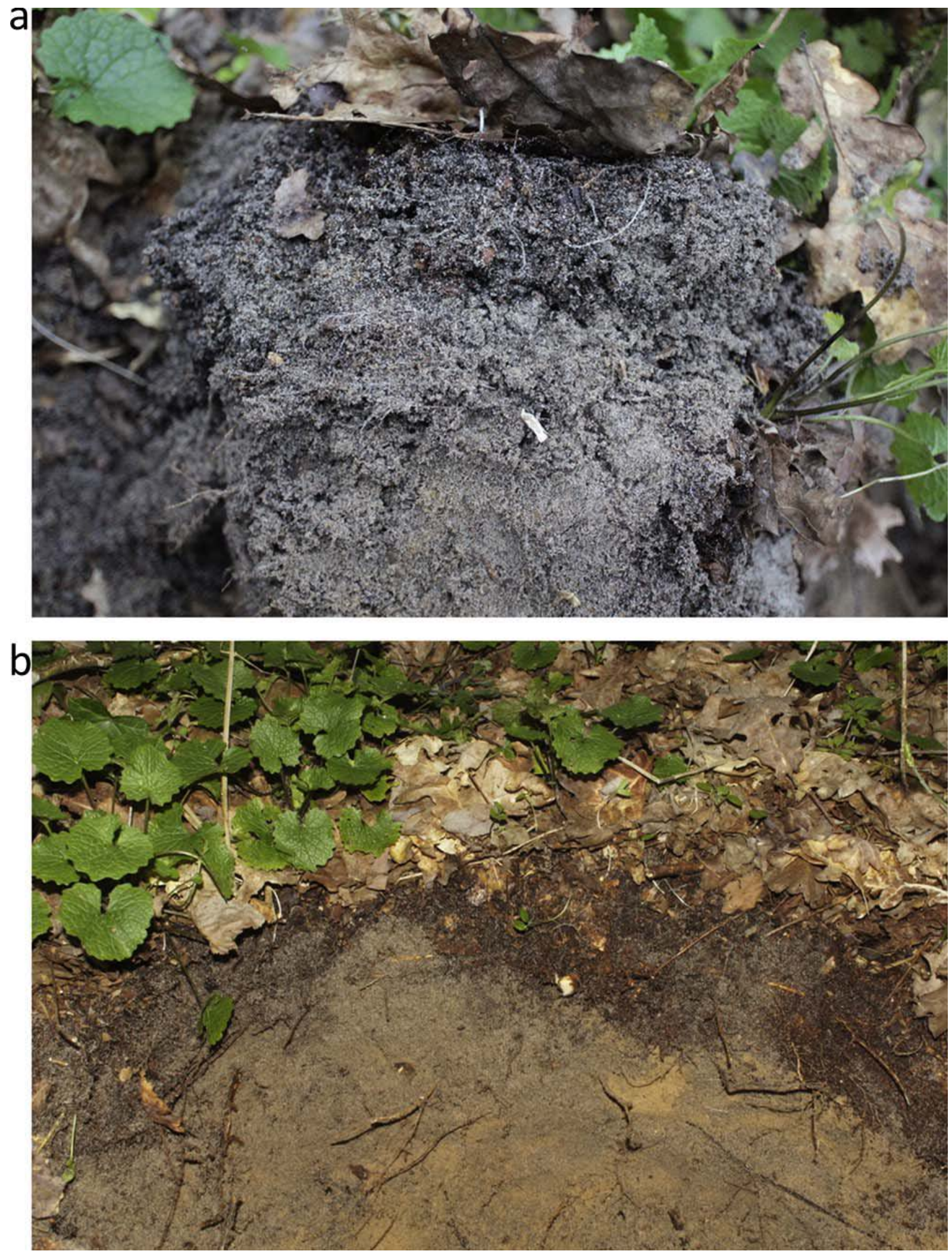

Fig. 11 

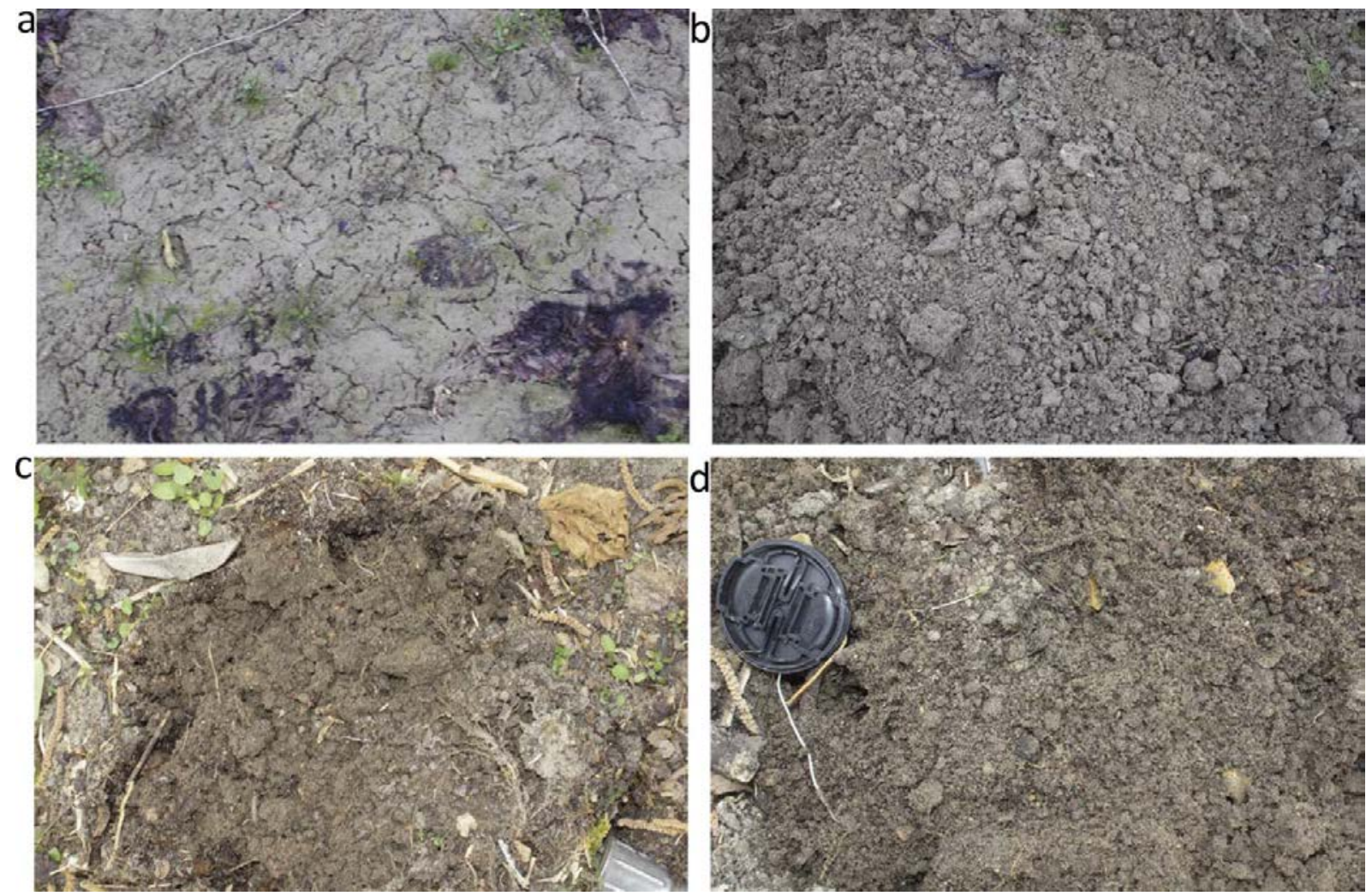

Fig. 12 

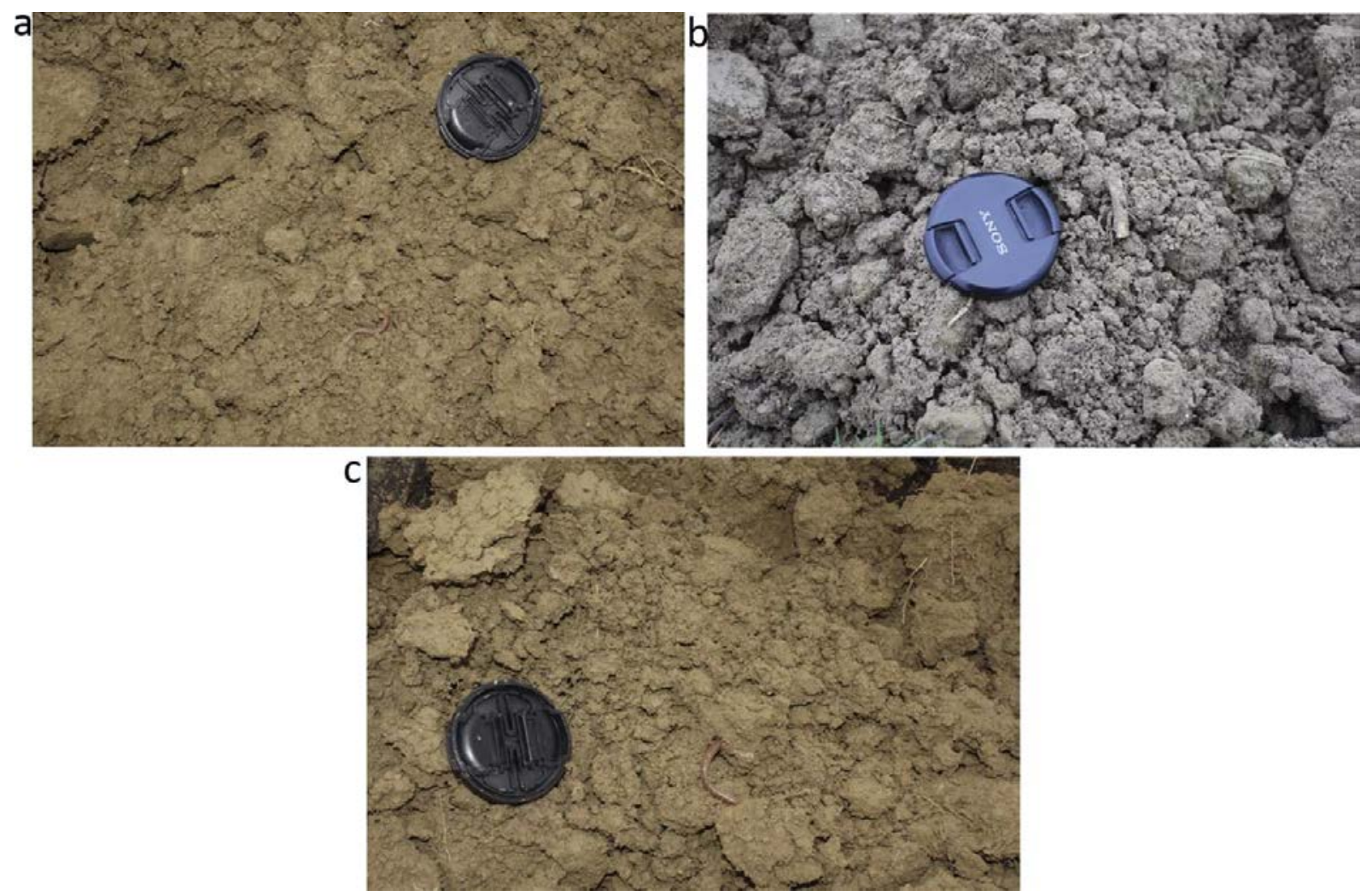

Fig. 13 
a ANTHROPOGENIC

Anthropogenic or natural

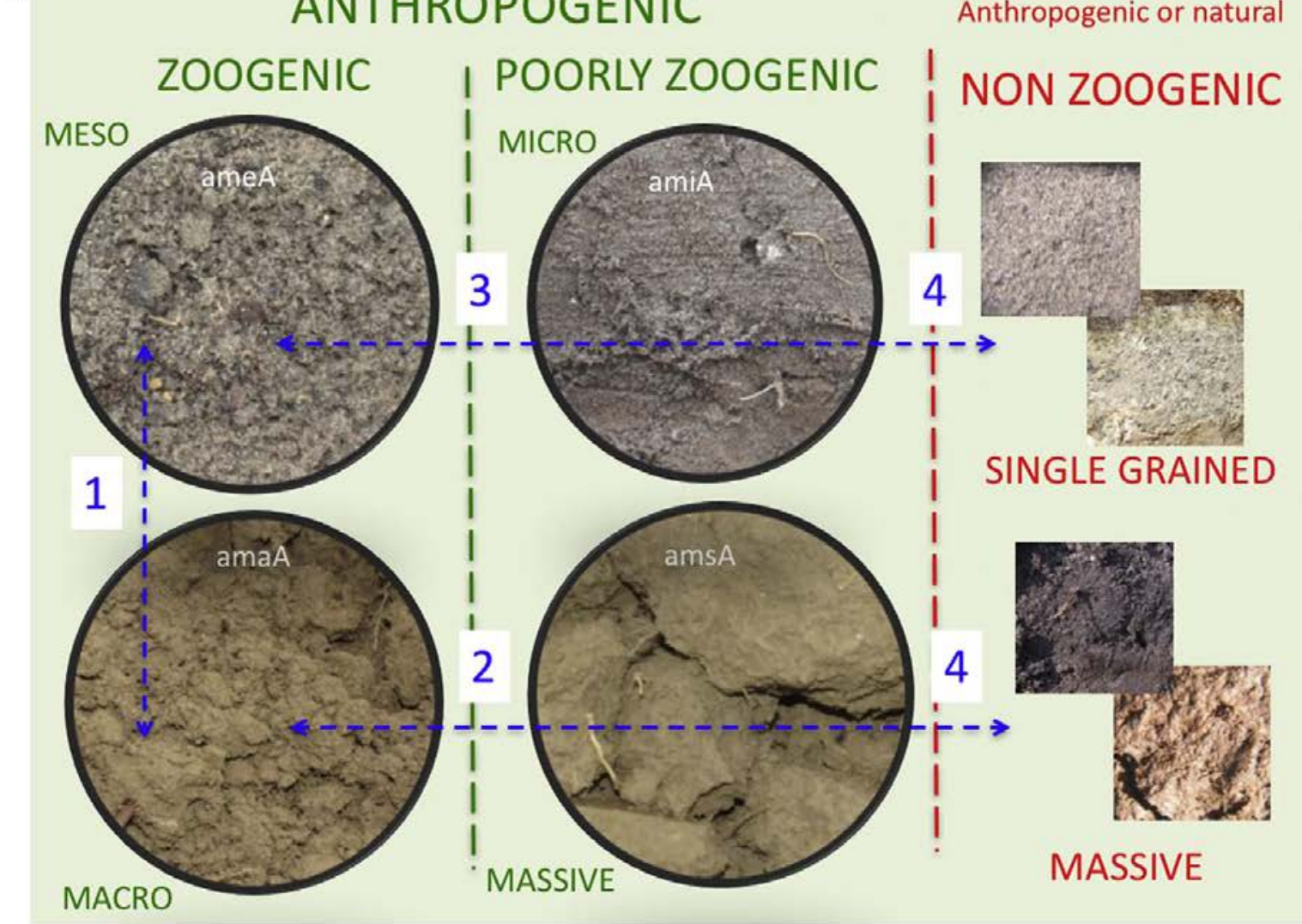

b

ZOOGENIC NATURAL STRUCTURES
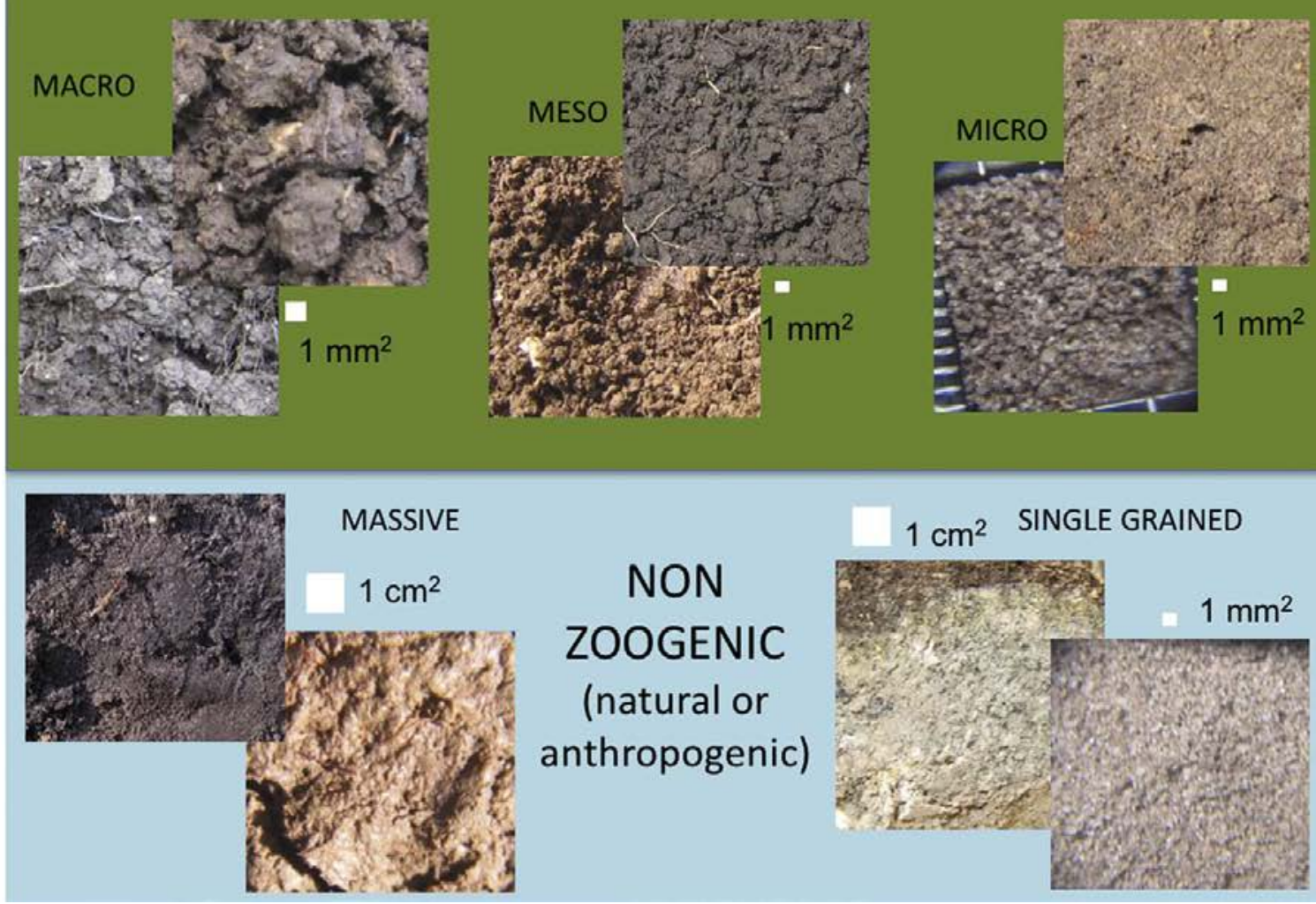

Fig. 14 

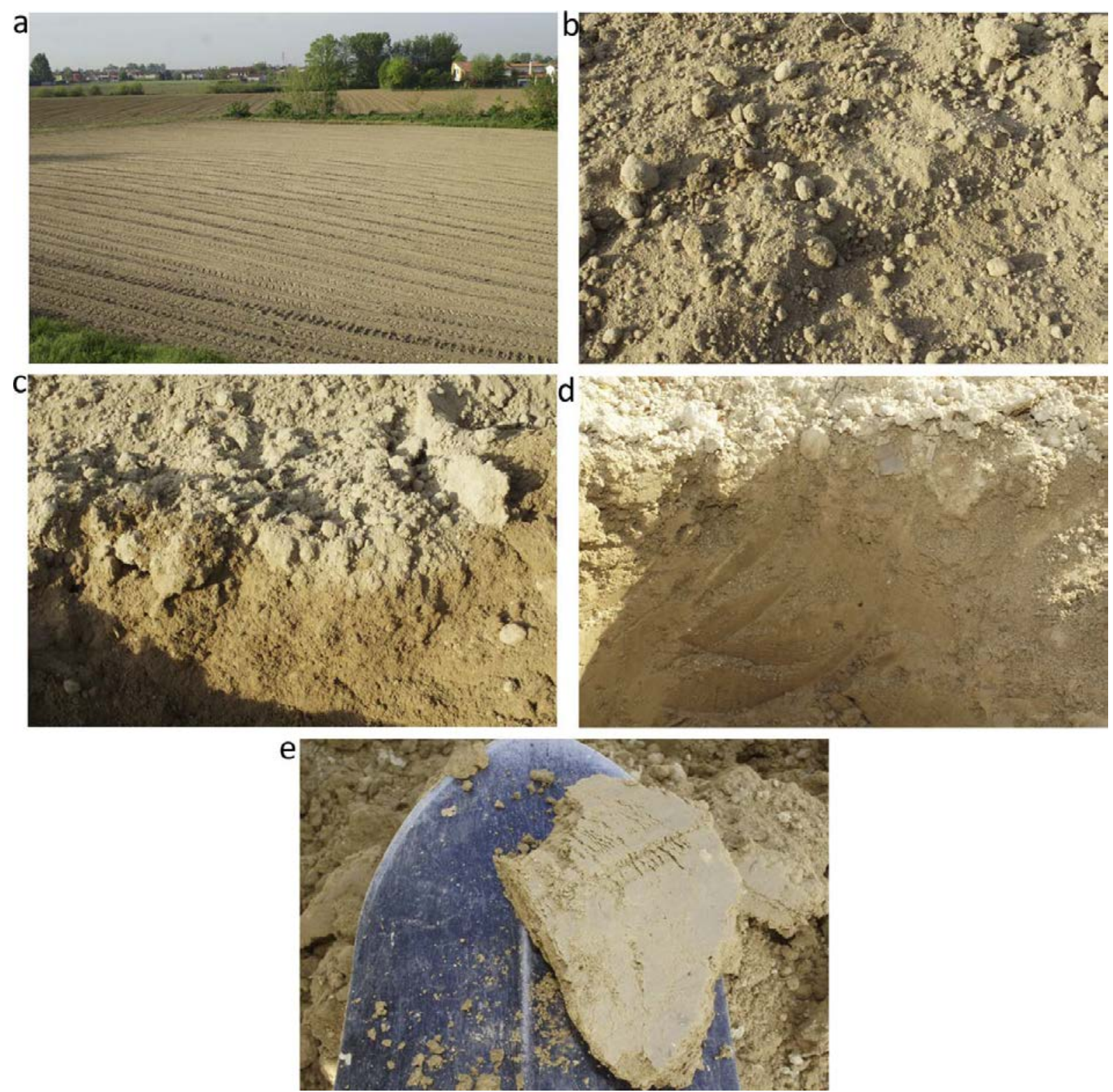

Fig. 15 

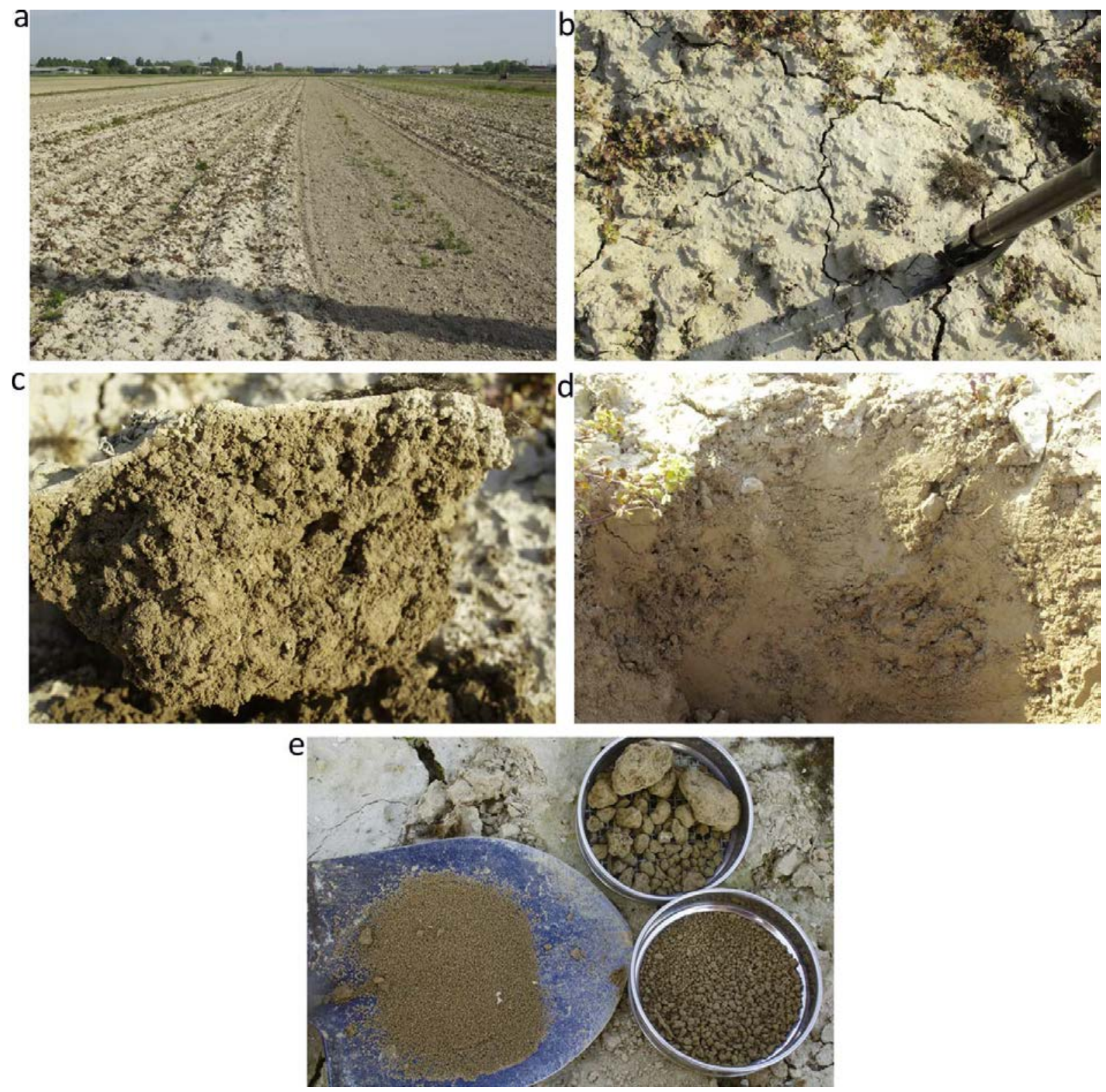

Fig. 16 


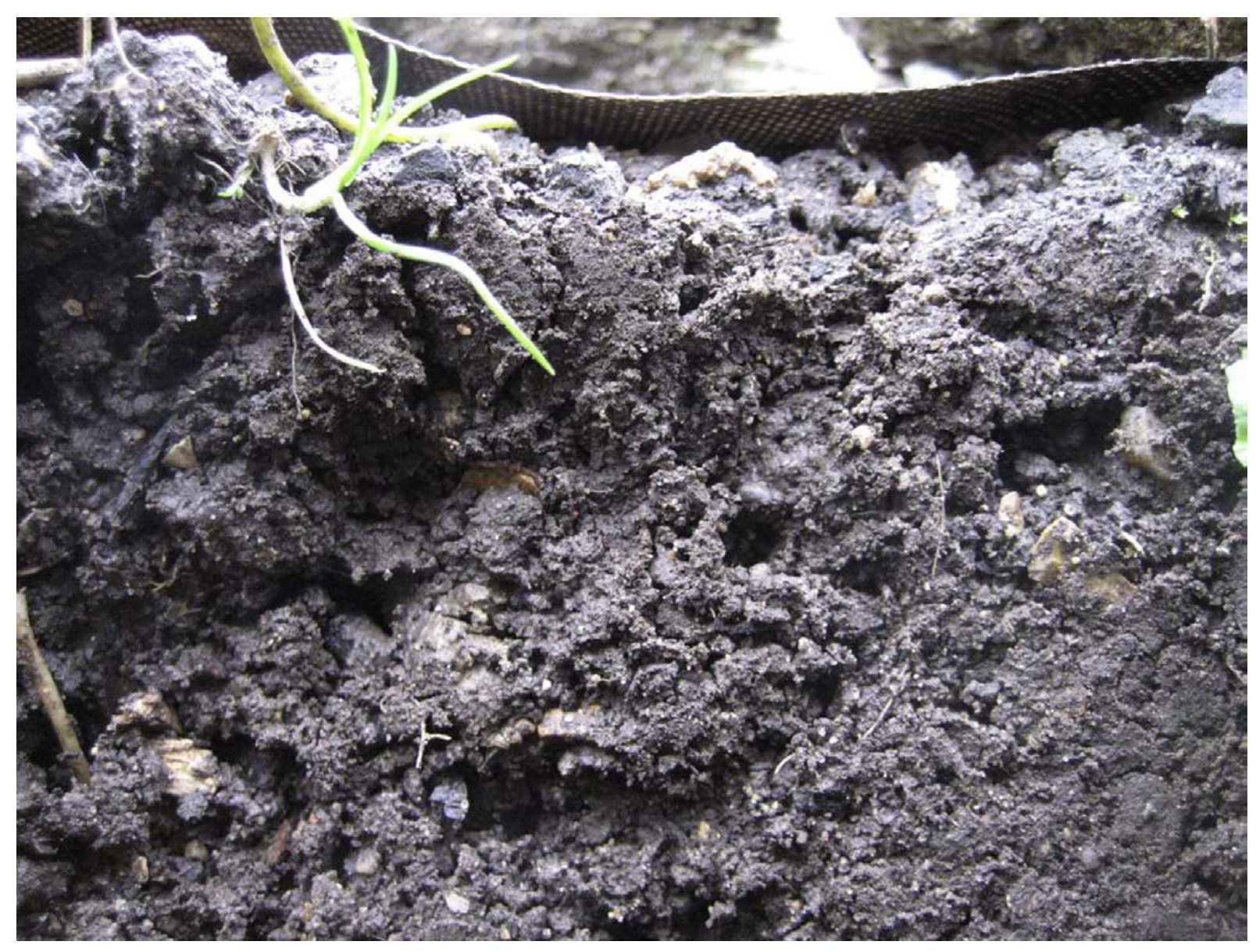

Fig. 17 


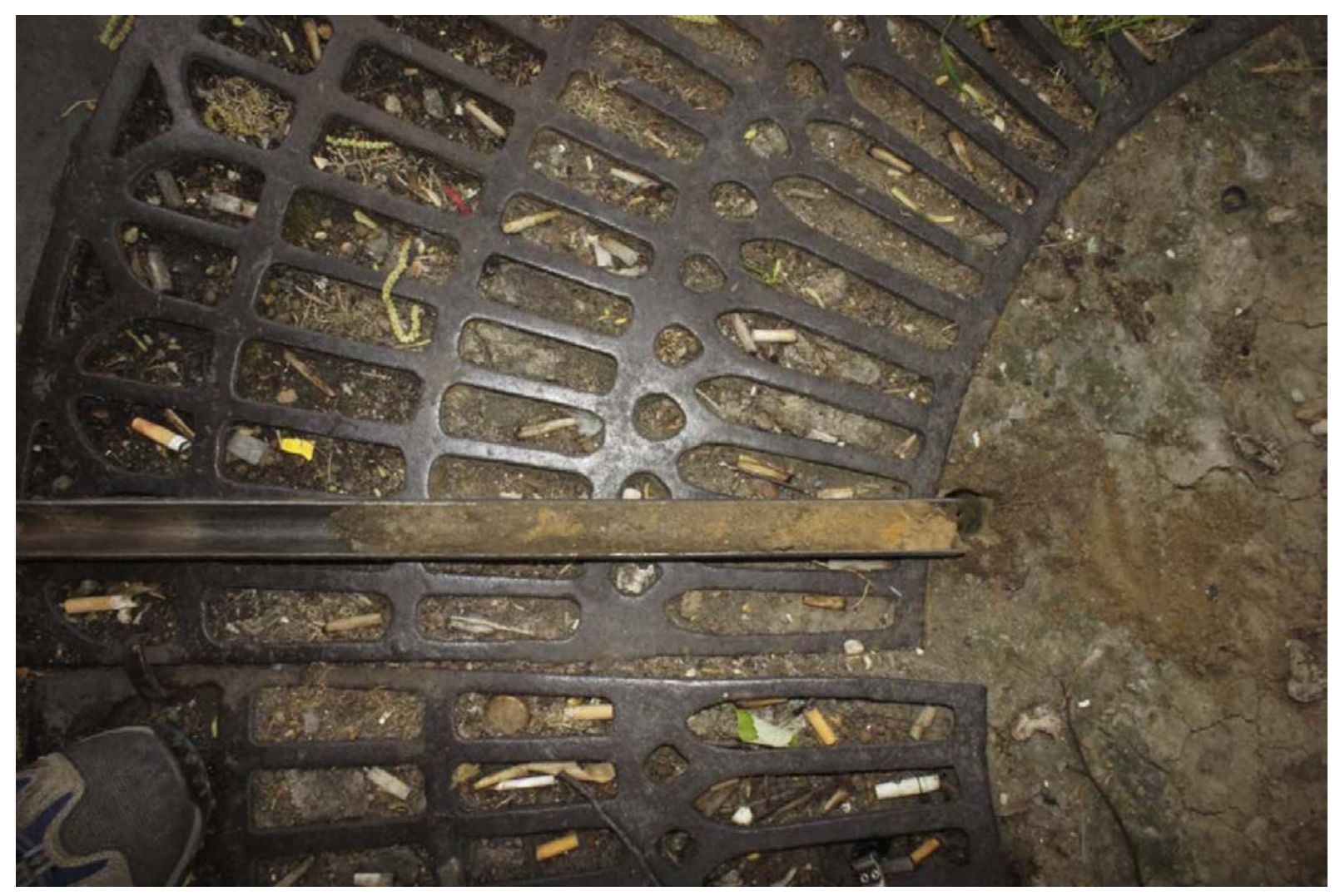

Fig. 18 

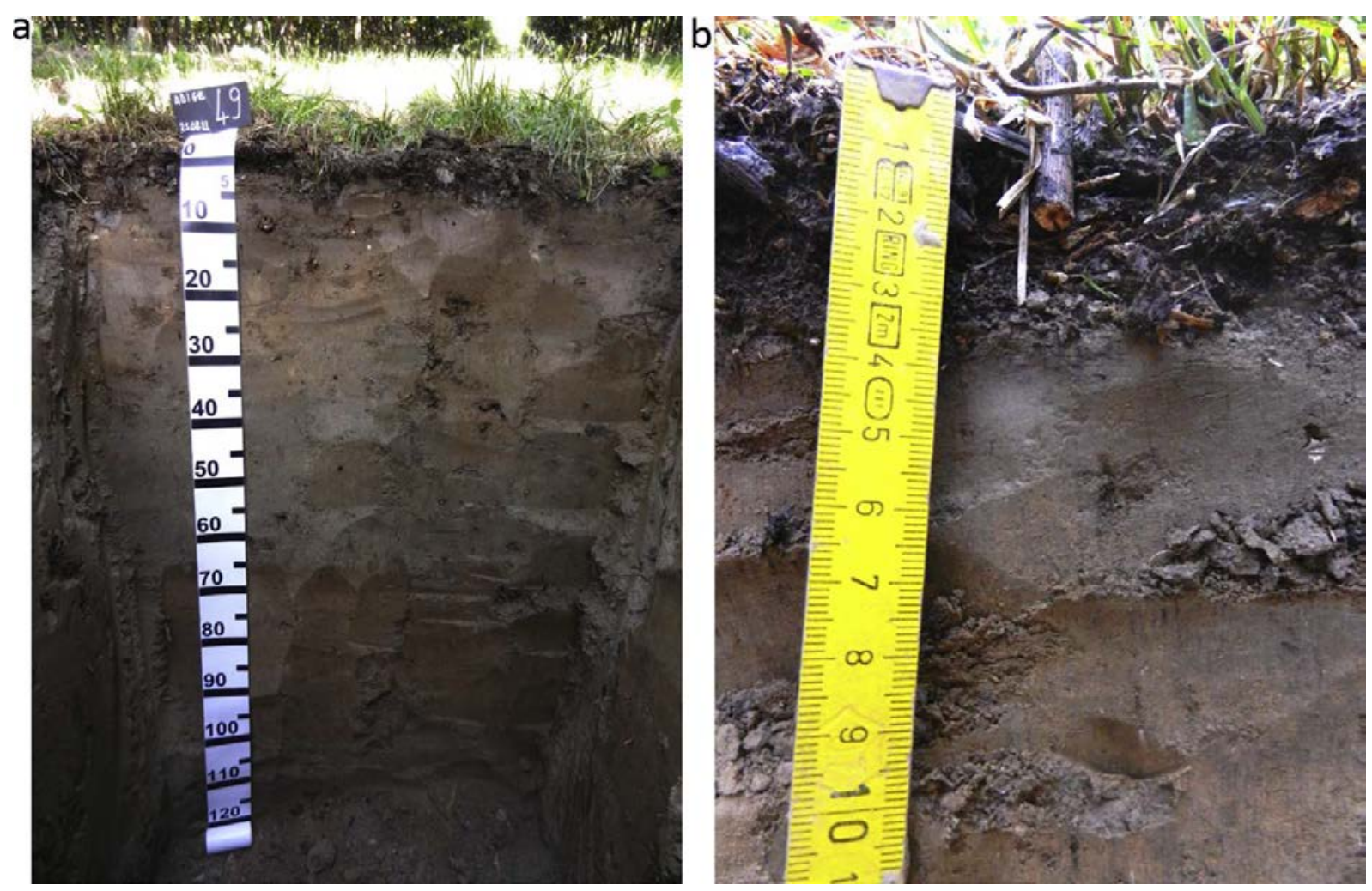

Fig. 19 

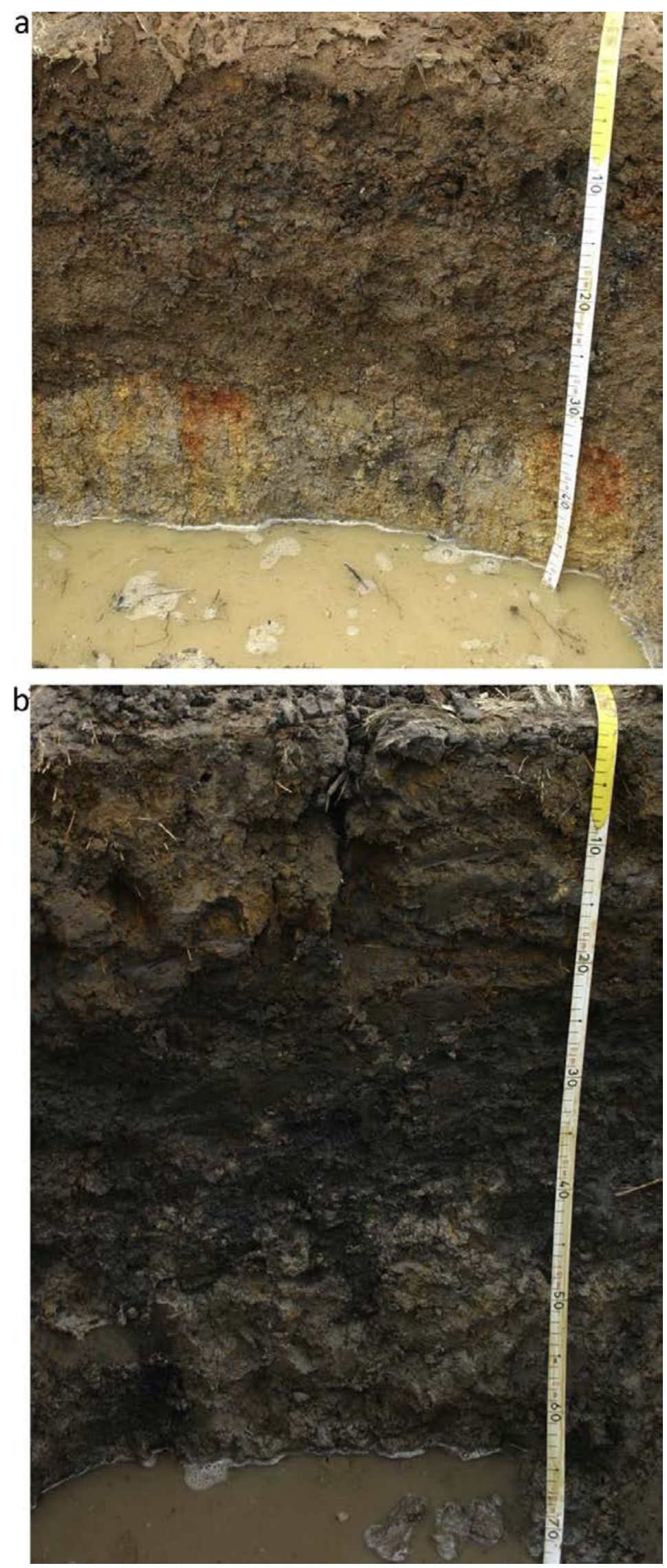

Fig. 20 